\title{
Benchmark Data for Validating Irradiated Fuel Compositions Used in Criticality Calculations
}

S. R. Bierman

R. J. Talbert

October 1994

Prepared for the U.S. Department of Energy Office of Civilian Radioactive Waste Management under Contract DE-AC06-76RLO 1830

Pacific Northwest Laboratory Operated for the U.S. Department of Energy by Battelle Memorial Institute 


\title{
DISCLAIMER
}

This report was prepared as an account of work sponsored by an agency of the United States Government. Neither the United States Government nor any agency thereof, nor Battelle Memorial Institute, nor any of their employees, makes any warranty, expressed or implied, or assumes any legal liability or responsibility for the accuracy, completeness, or usefulness of any information, apparatus, product, or process disclosed, or represents that its use would not infringe privately owned rights. Reference herein to any specific commercial product, process, or service by trade name, trademark, manufacturer, or otherwise does not necessarily constitute or imply its endorsement, recommendation, or favoring by the United States Government or any agency thereof, or Battelle Memorial Institute. The views and opinions of authors expressed herein do not necessarily state or reflect those of the United States Government or any agency thereof.

\author{
PACIFIC NORTHWEST LABORATORY \\ operated by \\ BATTELLE MEMORIAL INSTITUTE \\ for the \\ UNITED STATES DEPARTMENT OF ENERGY \\ under Contract DE-AC06-76RLO 1830
}

Printed in the United States of America

Available to DOE and DOE contractors from the

Office of Scientific and Technical Information, P.O. Box 62, Oak Ridge, TN 37831; prices available from (615) 576-8401. FTS 626-8401.

Available to the public from the National Technical Information Service, U.S. Department of Commerce, 5285 Port Royal Rd., Springfield, VA 22161. 


\section{DISCLAIMER}

Portions of this document may be illegible in electronic image products. Images are produced from the best available original document. 
PNL-10045

UC-722

\section{Benchmark Data For Validating Irradiated Fuel Compositions Used In Criticality Calculations}

S. R. Bierman

R. J. Talbert

October 1994

Prepared for the U.S. Department of Energy Office of Civilian Radioactive Waste Management under Contract DE-AC06-76RLO 1830

Pacific Northwest Laboratory Richland, Washington 99352 


$-$




\section{Summary}

To establish criticality safety margins utilizing burnup credit in the storage and transport of spent reactor fuels requires a knowledge of the uncertainty in the calculated fuel composition used in making the reactivity assessment. To provide data for validating such calculated burnup fuel compositions, radiochemical assays have been obtained as part of the United States Department of Energy FromReactor Cask Development Program. Assay results and associated operating histories on the initial three samples analyzed in this effort are presented. The three samples were taken from different axial regions of a Pressurized Water Reactor fuel rod and represent radiation exposures of about 37, 27, and $44 \mathrm{GWd} / \mathrm{MTU}$. The data are presented in a benchmark type format to facilitate identification/referencing and computer code input. 



\section{Contents}

Summary $\ldots \ldots \ldots \ldots \ldots \ldots \ldots \ldots \ldots \ldots \ldots \ldots \ldots \ldots \ldots \ldots$ iii

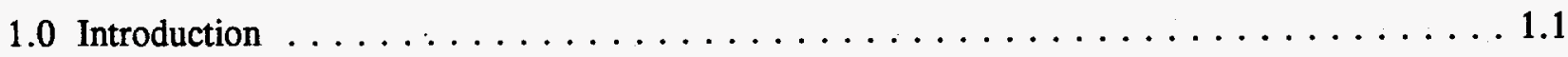

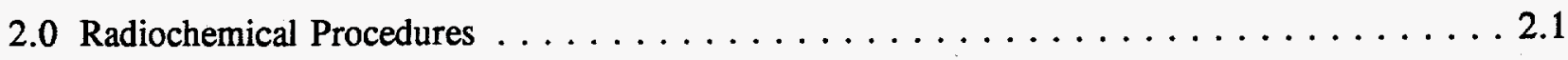

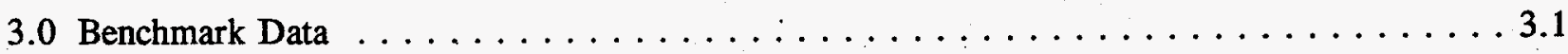

3.1 Pre-Irradiated and Irradiated Fuel Assays $\ldots \ldots \ldots \ldots \ldots \ldots \ldots \ldots \ldots \ldots \ldots$

3.2 Power History and Boron Concentration-Fuel Assembly D047,
Rod MKP109 $\ldots \ldots \ldots \ldots \ldots \ldots \ldots \ldots \ldots \ldots \ldots \ldots \ldots \ldots \ldots \ldots \ldots \ldots \ldots \ldots$

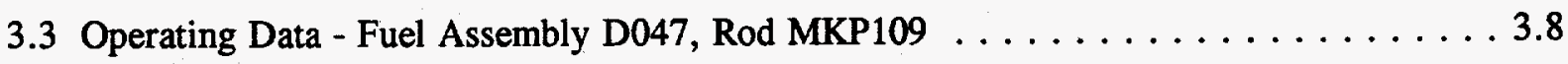

4.0 Conclusions and Recommendations $\ldots \ldots \ldots \ldots \ldots \ldots \ldots \ldots \ldots \ldots \ldots \ldots \ldots \ldots \ldots$

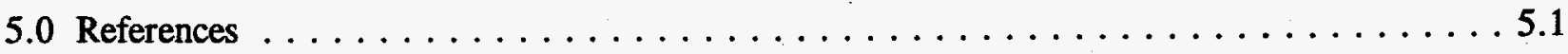

Appendix A - Separation and Analysis of Lanthanide Component
\[ \text { in Spent Fuel } \ldots \ldots \ldots \ldots \ldots \ldots \ldots \ldots \ldots \ldots \ldots \ldots \ldots \ldots \ldots \ldots \]

Appendix B - Estimated Uncertainties in Spent Fuel Sample Analyses . . . . . . . . . . . B.1

Appendix C - Pacific Northwest Mass Spectrometry Measurement Data . . . . . . . . . C.1

Appendix $\mathbf{D}-$ Los Alamos National Laboratory Mass Spectrometry
Measurement Data $\ldots \ldots \ldots \ldots \ldots \ldots \ldots \ldots \ldots \ldots \ldots$

Appendix E - Khlopin Radium Measurement Data $\ldots \ldots \ldots \ldots \ldots \ldots \ldots \ldots \ldots \ldots$

Distribution $\ldots \ldots \ldots \ldots \ldots \ldots \ldots \ldots \ldots \ldots \ldots \ldots \ldots \ldots \ldots \ldots \ldots \ldots \ldots \ldots$ 


\section{Figurés}

3.1 Gamma Scan of Rod MKP109 with Sampling Locations Indicated . . . . . . . . . . . 3.8

3.2 Location of Fuel Assembly in Reactor Core - Calvert Cliff No . . . . . . . . . . 3.10

3.3 Location of Fuel Rod in Assembly - Combustion Engineering

Fuel Assembly D047 . . . . . . . . . . . . . . . . . . 3.11 


\section{Tables}

3.1 Source and Pre-Irradiation Composition of Samples $\ldots \ldots \ldots \ldots \ldots \ldots \ldots$

3.2 Irradiated Composition of Fuel and Total Burnup - Fuel Assembly D047,

$\operatorname{Rod}$ MKP107 . . . . . . . . . . . . . . . . . . . . . . . . . . . 3.5

3.3 Power Histories and Boron Concentrations - Fuel Assembly D047, Rod MKP109 _ . . . 3.7

3.4 Operating Data - Duel Assembly DO47; Rod MKP109 . . . . . . . . . . . . . 3.9 


\subsection{Introduction}

Traditionally, criticality analyses of nuclear fuel storage and transport have assumed the systems contained unirradiated fuel. This assumption has been accepted as providing a significant criticality safety design margin without incurring undue costs and restrictions since operations were generally limited by heat transfer and shielding considerations. However, as irradiated fuels are aged out-of-reactors, criticality considerations begin to limit design and operations. The results of a study (Sanders, 1987) have indicated that considerable safety benefits and cost savings can be achieved in the transport of aged spent fuel if credit is taken for burnup (irradiation/cooling history) in the criticality design analyses of fuel transport systems.

To establish the criticality safety margin associated with a transport design utilizing burnup credit requires a knowledge of the uncertainty in the calculated fuel composition used in making the reactivity assessment. To provide data for validating such calculated burnup compositions, radiochemical assays have been obtained on a representative reactor fuel having experienced irradiation exposures up to about $44 \mathrm{GWd} / \mathrm{MTU}$. The data are presented in benchmark type format to facilitate identification/referencing and computer code input. The narrative associated with each benchmark is kept to the minimum required to clarify the data and identify its source.

Each sample assay consists of a set of radiochemical analytical data obtained by destructively assaying a spent fuel rod that had experienced a unique set of operating. conditions. The unique operating conditions associated with each sample analysis are specified to the extent required by current burnup calculational techniques. Also, the unirradiated composition and the source of the fuel rod sampled are presented. All of the samples destructively assayed were located away from any fuel assembly hardware such as end fittings and grid spacer plates. The presence or location of other perturbations such as water holes, fuel assembly boundaries, and burnable poisons are identified as part of the operating conditions. 


\subsection{Radiochemical Procedures}

The analytical procedures used for sample preparation, determining burnup, and analyzing for the indicated isotopic concentrations are briefly covered below. An estimate of the one standard deviation error limits on the analytical results obtained by each procedure is also provided.

Analysis

Sample Preparation

Burnup (including $\mathbf{U}$ and $\mathbf{P u}$ isotopes)

${ }^{241} \mathrm{Am}$
${ }^{135} \mathrm{Cs}$
${ }^{137} \mathrm{Cs}$
${ }^{99} \mathrm{Tc}$
${ }^{237} \mathrm{~Np}$

Lanthanides (except Nd)

\section{Description}

Weighed sample is dissolved in heated $12 \mathrm{~N} \mathrm{HNO}_{3}$ (+trace HF). Solution is separated from cladding and made up to $100 \mathrm{~mL}$. Aliquots are taken for subsequent analysis. Uncertainty associated with sample preparation: $\pm 1.0 \%$.

Fission product neodymium is chemically separated from irradiated fuel and determined by isotopic dilution mass spectrometry. Enriched ${ }^{150} \mathrm{Nd}$ is used as the ND isotope diluent, and mass 142 is used to determine natural Nd contamination. Uranium and plutonium are also determined by mass spectrometry. The method uses a calibrated triple spike of ${ }^{150} \mathrm{Nd},{ }^{233} \mathrm{U}$, and ${ }^{242} \mathrm{Pu}$ per ANSI/ASTM Standard Test Method E-321-79. Total uncertainty. Atom \% burnup, $\pm 2.5 \%$; $\mathrm{Pu}, \pm 1.6 \% ; \mathrm{U}, \pm 1.6 \%$.

Americium is separated, along with curium, using cation and anion exchange and determined by alpha spectrometry. Uncertainty: ${ }^{241} \mathrm{Am}, \pm 4.9 \%$.

Cesium is separated from other elements by chromatographic elution from a cation exchange column. Isotopic abundance of the cesium isotope is determined by mass spectrometry. Uncertainty: $\pm 14 \%$.

The cesium is determined by gamma ray spectrometry on an aliquot of the aqueous solution. Uncertainty. $\pm 3.5 \%$.

Technetium is separated from other radioactive species by a process that absorbs most of the other species onto a cation exchange resin. The technetium is extracted from the effluent into hexone as tetraphenylarsonium pertechnetate. The technetium activity is then measured by beta counting. Uncertainty: $\pm 3.5 \%$.

Neptunium-237 is separated from other radionuclides species by extraction into a mixture of triiso-octylamine (TIOA) in xylene, stripped from the TIOA phase with $\mathrm{HCl}$ and re-extraction into a mixture of thenoly-trifluoro acetone (TTA) in xylene for additional separation. Neptunium-237 is measured by alpha counting. $A{ }^{239} \mathrm{~Np}$ tracer is added to the sample and gamma-counted to determine a recovery factor. Uncertainty: $\pm 1.9 \%$.

The lanthanide elements are separated from the dissolved fuel sample by extraction chromatography followed by cation exchange per Pacific Northwest Laboratories Technical Procedure PNLALO-498. (Procedure developed for these assays. See Appendix A for more detailed information.) Individual lanthanide concentrations are determined from Inductively Coupled Plasma-Mass Spectrometry measurements relative to ${ }^{145} \mathrm{Nd}$ and ${ }^{143} \mathrm{Nd}$. Uncertainty: See Appendix B. 


\subsection{Benchmark Data}

Radiochemical assays of Pressurized Water Reactor fuel samples having experienced irradiations of $27.35,37.12$, and $44.34 \mathrm{GWd} / \mathrm{MTU}$ are presented in this benchmark. The three samples were obtained from different axial locations in a single fuel rod corresponding to maximum burnup and approximately $85 \%$ and $60 \%$ of maximum burnup. Thus, the benchmark provides composition data as a function of fuel burnup and data on the axial dependency of burnup within the same rod.

\subsection{Unirradiated and Irradiated Fuel Assays}

As indicated in the unirradiation description of the fuel samples, the samples were obtained from a Combustion Engineering fuel assembly. The assembly had experienced four irradiation cycles in the Calvert Cliff Unit No. 1 reactor. Except for the lanthanides, the samples had been previously analyzed by the Department of Energy's Materials Characterization Center (MCC) at the Pacific Northwest Laboratories. Results of these MCC analyses that are of interest to criticality calculations are included as part of the chemical compositions presented herein. The unirradiated fuel data and fuel assembly information was provided by Combustion Engineering and by Baltimore Gas and Electric Company (Combustion Engineering, 1986; Baltimore Gas and Electric Company, 1968). Additional information can be obtained from PNL-5109-104 (Guenther, 1991).

As stated in Section 2, the lanthanide isotope concentrations, except for the neodiniums, were determined by mass spectrometry measurements. As a consequence, irradiated concentrations for four of the nuclides of interest to criticality calculations are based on measurement data contaminated with significant quantities of nuclides of more than one element. These are nuclides having mass numbers 147 (Pm, Sm), 150 (Nd, Sm), $151(\mathrm{Sm}, \mathrm{Eu})$ and $155(\mathrm{Eu}, \mathrm{Gd})$. These measurement data have been adjusted using calculated values to obtain the concentrations shown in the table on irradiated compositions. The measurement data and the associated adjustments made to these four sets of data are presented in the paragraphs that follow. The mass spectrometry measurement data for all the lanthanides can be found in Appendix C.

Based on calculations, ${ }^{(a)}$ about $3.48 \%$ of the isobar for mass number 147 was due to

(a) ORIGEN-S calculated results using SAS2 27-group ENDF/B4 library. Facsimile communication of only the results received from C. V. Parks, Oak Ridge National Laboratory, June 18, 1993. 
Pm in the $27.35 \mathrm{GWd} / \mathrm{MTU}$ spent fuel sample. Similarly, the $37.12 \mathrm{GWd} / \mathrm{MTU}$ and the $44.34 \mathrm{GWd} / \mathrm{MTU}$ samples contained about $3.49 \mathrm{wt} \% \mathrm{Pm}$ and $3.51 \mathrm{wt} \% \mathrm{Pm}$, respectively. The measured concentration of mass number 147 in the three samples $\left(0.221 \mathrm{mg} / \mathrm{gUO}_{2}\right.$, $0.254 \mathrm{mg} / \mathrm{gUO}_{2}$, and $0.268 \mathrm{mg} / \mathrm{gUO}_{2}$, respectively) were corrected, using a half life of $2.623 \mathrm{yr}$, for change in Pm content from June, 1987 to the time of measurement (October, 1992) to obtain the ${ }^{147} \mathrm{Sm}$ concentrations given in the table on irradiated compositions.

As stated above, ${ }^{150} \mathrm{Nd}$ concentrations in the samples were obtained by a second independent measurement method. The values given in the table for ${ }^{150} \mathrm{Sm}$ were obtained by taking the difference between these independently measured data and the mass spectrometry measurement data for mass number 150 . Although the ${ }^{150} \mathrm{Nd}$ is not of interest to criticality calculations, the independently measure value is given in the table for completeness.

Both components ( $\mathrm{Sm}$ and $\mathrm{Eu}$ ) in the isobar for mass number 151 are essentially stable relative to the time difference between June 1987 and the time of measurement (October, 1992). Consequently, the measured isobaric data were adjusted based on calculated values $^{(a)}$ of $7.95 \mathrm{wt} \%, 7.89 \mathrm{wt} \%$, and $7.85 \mathrm{wt} \% \mathrm{Eu}$ in the isobaric data, respectively, for the $27.35 \mathrm{GWd} / \mathrm{MTU}$, the $37.12 \mathrm{GWd} / \mathrm{MTU}$ and the $44.34 \mathrm{GWd} / \mathrm{MTU}$ samples. The total concentration for mass number 151 in each of the three samples was measured at $0.934 \mathrm{E}-02 \mathrm{mg} / \mathrm{gUO}_{2}, 0.930 \mathrm{E}-02 \mathrm{mg} / \mathrm{g} \mathrm{UO}_{2}$ and $0.978 \mathrm{E}-02 \mathrm{mg} / \mathrm{gUO}_{2}$, respectively.

Calculations $^{(\mathrm{a})}$ indicate the isobar for mass number 155 contained about $20.99 \mathrm{wt} \% \mathrm{Eu}$ for the $27.35 \mathrm{GWd} / \mathrm{MTU}$ sample, about $21.05 \mathrm{wt} \%$ for the $37.12 \mathrm{GWd} / \mathrm{MTU}$ sample and about $21.09 \mathrm{wt} \%$ for the $44.34 \mathrm{GWd} / \mathrm{MTU}$ sample. As with mass number 147 , the measured concentrations $\left(0.474 \mathrm{E}-02 \mathrm{mg} / \mathrm{gUO}_{2}, 0.710 \mathrm{E}-02 \mathrm{mg} / \mathrm{gUO}_{2}\right.$ and $0.982 \mathrm{E}-02$ $\mathrm{mg} / \mathrm{gUO}_{2}$, respectively) for mass number 155 were adjusted using these calculated values and corrected from June, 1987 to the time of measurement (October, 1992) using a half life of $4.68 \mathrm{yr}$ for ${ }^{155} \mathrm{Eu}$, to obtain the ${ }^{155} \mathrm{Gd}$ and the ${ }^{155} \mathrm{Eu}$ concentrations given in the table on irradiated compositions.

Except for the lanthanide elements, estimated one sigma error limits are given in Section 2 for the measurement results presented in Table 3.2. To obtain data for estimating the error limits associated with the lanthanides, sample 87-81 was analyzed by the Los Alamos National Laboratory (LANL) and the Khlopin Radium Institute (KRI) in

(a) ORIGEN-S calculated results using SAS2 27-group ENDF/B4 library. Facsimile communication of only the results received from C. V. Parks, Oak Ridge National Laboratory, June 18, 1993. 
addition to the Pacific Northwest Laboratories (PNL). One sigma standard deviation error limits (in units of weight $\%$ ) for each of the lanthanides are summarized below:

$$
\begin{aligned}
& \text { M-155 29\% (b) } \\
& \text { Eu-153 2\% } \\
& \text { Sm-152-3\% } \\
& \text { Sm-151 7\% } \\
& \text { Sm-150 2\% } \\
& \text { Sm-149-18\% } \\
& \text { Sm-147 4\% } \\
& \text { Nd-145<1\% } \\
& \text { Nd-143<1\% }
\end{aligned}
$$

Analyses of the three sets of data to obtain the above estimated error limits are presented in Appendix B. The complete LANL measurement data are presented in Appendix D. The complete KRI measurement data are presented in Appendix E. The KRI measurements include mass spectrometry data before and after chemical separation of the lanthanides into individual elements. The LANL and PNL measurements involved only mass spectrometry measurements without chemical separation into elemental lanthanides.

Some of the earlier spent fuel analyses data were reported in curies per gram of fuel by the Material Characterization Center in PNL-5109-104 (Guenther, 1991). For inclusion in Table 3.1, these analytical results have been converted to $\mathrm{mg} / \mathrm{g}$ fuel using the respective half-life values as indicated below:

\begin{tabular}{clll} 
ISOTOPE & & HALF LIFE \\
\cline { 1 - 1 } $99-\mathrm{Tc}$ & & $2.1 \mathrm{E}+05 \mathrm{y}$ \\
$135-\mathrm{Cs}$ & & $2.3 \mathrm{E}+06 \mathrm{y}$ \\
$137-\mathrm{Cs}$ & & $30.2 \mathrm{y}$ \\
$237-\mathrm{Np}$ & & $2.14 \mathrm{E}+06 \mathrm{y}$ \\
$241-\mathrm{Am}$ & & $432 \mathrm{y}$
\end{tabular}

(b) Mass isobar at mass 155 
Table 3.1 Source and Unirradiated Composition of Samples

\begin{tabular}{|c|c|}
\hline Reactor & Calvert Cliffs No. 1 \\
\hline Fuel Assembly & Combustion Engineering D047 \\
\hline Assembly Spacing, $\mathrm{cm}$ & 20.78, center-to-center \\
\hline Assembly Cross Section, $\mathrm{cm}$ & $20.27 \times 20.27$, outside fuel rods \\
\hline Fuel Rod Arrangement & $14 \times 14,1.473 \mathrm{~cm}$ center to center \\
\hline Fuel Rod & MKP109 \\
\hline Approved Testing Material No. & ATM104 ${ }^{(a)}$ \\
\hline \multicolumn{2}{|l|}{ Fuel Pellet } \\
\hline Material & $\mathrm{UO}_{2}(\mathrm{CE}$ Lot B-71-GB) \\
\hline Diameter, cm & 0.9563 \\
\hline Length, $\mathrm{cm}$ & 1.143 \\
\hline Density, $\mathrm{g} / \mathrm{cm}^{3}$ & $10.36-10.48$ \\
\hline Grain size, $\mu \mathrm{m}$ & 25 \\
\hline \multicolumn{2}{|l|}{ Unirradiated Fuel Composition } \\
\hline Uranium, wt\% & $88.143 \pm 0.010$ \\
\hline $\begin{array}{l}\text { O:U Atom Ratio } \\
{ }^{234} \mathrm{U}, \mathrm{wt} \%\end{array}$ & $\begin{array}{l}2.001 \pm 0.002 \\
0.025^{(b)}\end{array}$ \\
\hline${ }^{235} \mathrm{U}, \mathrm{wt} \%$ & 3.038 \\
\hline${ }^{236} \mathrm{U}, \mathrm{wt} \%$ & $0.025^{(b)}$ \\
\hline Carbon, ppm & $17.5 \pm 6.1$ \\
\hline Nitrogen, ppm & $23.2 \pm 8.3$ \\
\hline Fluorine, ppm & $<5$ \\
\hline Chlorine and Fluorine, ppm & $<10$ \\
\hline Iron, ppm & $<45$ \\
\hline Silver, ppm & $<1$ \\
\hline Aluminum, ppm & $<115$ \\
\hline Silicon & -- \\
\hline Nickel & $<25$ \\
\hline \multicolumn{2}{|l|}{ Cladding } \\
\hline Material & Zircaloy-4 (Sandvik Lot 5FP65) \\
\hline Outside Diameter, $\mathrm{cm}$ & 1.118 \\
\hline Inside Diameter, $\mathrm{cm}$ & 0.986 \\
\hline Density, $\mathrm{g} / \mathrm{cm}^{3}$ & $6.32^{(b)}$ \\
\hline
\end{tabular}

(a) See PNL-5109-104, Guenther, 1991.

(b) Nominal values, not part of fuel certification data. 
Table 3.2 Irradiated Composition ${ }^{(a)}$ of Fuel and Total Burnup - Fuel Assembly D047, Rod MKP109

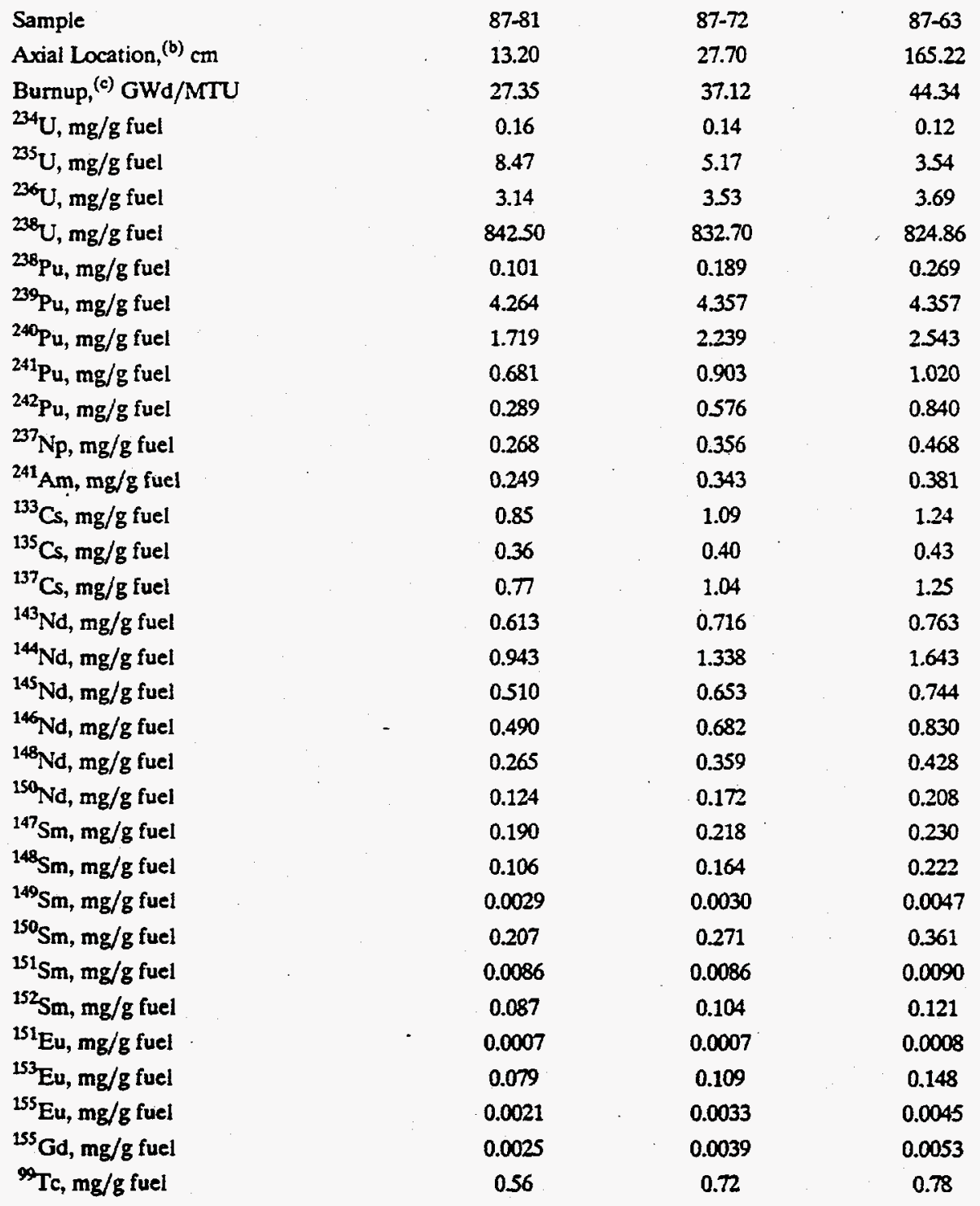

(a) Radiochemical analyses performed during June 1987, or corrected for decay to June 1987.

(b) From bottom of fuel.

(c) Burnup based on measured ${ }^{148} \mathrm{Nd}$ concentration (ASTM 1985). 


\subsection{Power History and Boron Concentration-Fuel Assembly D047, Rod MKP109}

The power histories and axial distributions reported for each reactor cycle in the table that follows were obtained from reactor operating records. For each operating cycle, time dependent axial power distribution data were available on each fuel assembly along with the assembly average power density. However, only time dependent average power densities existed for individual fuel rods in each fuel assembly. The time dependent average power densities for the specific fuel rod (MKP109) and the time dependent average power density for fuel assembly (D047) were used to ratio that fuel assembly's axial power density distribution to obtain a local heat generation rate for each of the axial locations at which sample analyses data are presented.

As indicated in the power history tables, each irradiation cycle is divided into time intervals of differing lengths. The operating records report these simply as time points. To calculate the length of each interval in days, the initial metal density of the fuel, the rod burnup over a given time interval and the average linear heat generation rate in the rod for that time interval were used.

The average soluble boron concentration for each time interval during a reactor cycle was also obtained from reactor operating records. The value given for each time interval in the tables that follow is the arithmetic mean of the boron concentration at the beginning and end of the time interval.

A ${ }^{137}$ Cs gamma scan of rod MKP109 is also presented in this section to illustrate the axial irradiation experienced by the fuel rod and to indicate the axial locations of the samples referred to in Section 3.1. The sampling points are identified as P, CC and LL. The gamma scan also provides a means of predicting axial burnup in the fuel rod. It has been demonstrated (Guenther, 1991) that the ${ }^{137} \mathrm{Cs}$ activity is a linear function of fuel burnup. The linear relationship determined (Guenther, 1991) for rod MKP109 is:

$\mathrm{BU}=0.0222 \mathrm{~A}-6.8$,

where $A$ is the measured activity (counts per second) presented in the gamma scan and BU (MWd/MTU) is the burnup at any axial location of rod MKP109. Thus the gamma scan can be used to develop an axial burnup profile if desired. 
Table 3.3 Power Histories and Boron Concentrations-Fuel Assembly D047, Rod MKP109

CYCLE No. 2

3-22-77 to 1-22-78

\begin{tabular}{|c|c|c|c|c|}
\hline \multirow[b]{2}{*}{$\begin{array}{l}\text { Interval } \\
\text { days }\end{array}$} & \multirow{2}{*}{$\begin{array}{l}\text { Average } \\
\text { Soluble } \\
\text { Boron, } \\
\text { ppm }\end{array}$} & \multicolumn{3}{|c|}{ LHGR (a) $\mathrm{kW} / \mathrm{ft}$} \\
\hline & & $13.20 \mathrm{~cm}$ & $27.70 \mathrm{~cm}$ & $165.22 \mathrm{~cm}$ \\
\hline 7.0 & 654 & 2.0 & 3.04 & 5.42 \\
\hline 30.8 & 614 & 2.73 & 4.08 & 6.64 \\
\hline 16.3 & 563 & 2.80 & 4.18 & 6.60 \\
\hline 11.4 & 533 & 2.86 & 4.26 & 6.60 \\
\hline 12.5 & 507 & 2.94 & 4.34 & 6.56 \\
\hline 23.7 & 468 & 3.01 & 4.43 & 6.41 \\
\hline 22.8 & 418 & 3.16 & 4.61 & 6.44 \\
\hline 23.2 & 368 & 3.27 & 4.73 & 6.37 \\
\hline 8.1 & 333 & 3.30 & 4.75 & 6.34 \\
\hline 31.4 & 290 & 3.48 & 4.95 & 6.34 \\
\hline 34.3 & 218 & 3.59 & 5.05 & 6.53 \\
\hline 16.4 & 162 & 3.75 & 5.25 & 6.38 \\
\hline 19.2 & 122 & 3.75 & 5.21 & 6.26 \\
\hline 12.8 & 86 & 3.81 & 5.28 & 6.30 \\
\hline 34.2 & 36 & 3.63 & 4.98 & 5.95 \\
\hline 1.9 & 0 & 3.64 & 4.98 & 5.96 \\
\hline 71 & $\mathbf{0}$ & 0 & 0 & $\underline{0}$ \\
\hline
\end{tabular}

CYCLE No. 3

4-3-78 to 4-20-79

\begin{tabular}{|c|c|c|c|c|}
\hline \multirow[b]{2}{*}{$\begin{array}{l}\text { Interval } \\
\text { davs }\end{array}$} & \multirow{2}{*}{$\begin{array}{l}\text { Average } \\
\text { Soluble } \\
\text { Boron, } \\
\text { ppm }\end{array}$} & \multicolumn{3}{|c|}{$\mathrm{LHGR}^{(\mathrm{a})} \mathrm{kW} / \mathrm{ft}$} \\
\hline & & $13.20 \mathrm{~cm}$ & $27.70 \mathrm{~cm}$ & $165.22 \mathrm{~cm}$ \\
\hline 7.9 & 883 & 2.63 & 3.85 & 7.47 \\
\hline 14.4 & 862 & 2.71 & 3.95 & 7.20 \\
\hline 19.7 & 837 & 2.14 & 3.11 & 5.04 \\
\hline 16.8 & 808 & 3.18 & 4.58 & 7.79 \\
\hline 16.3 & 775 & 3.35 & 4.81 & 7.78 \\
\hline 15.4 & 741 & 3.74 & 5.33 & 8.16 \\
\hline 39.1 & 684 & 3.71 & 5.23 & 7.45 \\
\hline 31.2 & 611 & 3.95 & 550 & 7.37 \\
\hline 31.8 & $\$ 45$ & 4.08 & 5.64 & 7.20 \\
\hline 31.8 & 478 & 4.20 & 5.75 & 7.02 \\
\hline 44.3 & 368 & 4.38 & 5.93 & 6.93 \\
\hline 25.0 & 291 & 0 & 0 & 0 \\
\hline 59.1 & 224 & 4.67 & 6.20 & 6.89 \\
\hline 28.9 & 120 & 4.95 & 6.52 & 7.12 \\
\hline 81 & 83 & 0 & 0 & 0 \\
\hline
\end{tabular}

CYCLE No. 4 $7-10-79$ to $10-18-80$

\begin{tabular}{|c|c|c|c|c|}
\hline \multirow[b]{2}{*}{$\begin{array}{l}\text { Interval } \\
\text { days }\end{array}$} & \multirow{2}{*}{$\begin{array}{l}\text { Average } \\
\text { Soluble } \\
\text { Boron, } \\
\text { ppm }\end{array}$} & \multicolumn{3}{|c|}{$\mathrm{LHGR}_{1}^{\left({ }^{(a)} \mathrm{kW} / \mathrm{ft}\right.}$} \\
\hline & & $13.20 \mathrm{~cm}$ & $27.70 \mathrm{~cm}$ & $165.22 \mathrm{~cm}$ \\
\hline 46.1 & 960 & 2.79 & 3.97 & 6.59 \\
\hline 24.0 & 889 & 2.91 & 4.11 & 6.54 \\
\hline 22.6 & 827 & 3.07 & 4.29 & 6.43 \\
\hline 25.7 & 759 & 3.29 & 4.56 & 6.33 \\
\hline 30.2 & 706 & 1.57 & 2.17 & 3.05 \\
\hline 41.2 & 788 & 1.79 & 2.46 & 3.18 \\
\hline 50.3 & 720 & 1.72 & 2.35 & 3.00 \\
\hline 11.0 & 673 & 3.18 & 4.33 & 5.23 \\
\hline 32.8 & 527 & 3.93 & 5.31 & 6.17 \\
\hline 23.5 & 460 & 4.07 & 5.42 & 6.12 \\
\hline 29.4 & 370 & 4.05 & 5.35 & 5.95 \\
\hline 28.1 & 301 & 4.25 & 5.56 & 6.07 \\
\hline 65.4 & 191 & 4.42 & 5.67 & 5.98 \\
\hline 35.7 & 73 & 4.62 & 5.87 & 6.02 \\
\hline 85 & 31 & 0 & 0 & 0 \\
\hline
\end{tabular}

CYCLE No. 5 1-11-81 to 4-17-82

\begin{tabular}{|c|c|c|c|c|}
\hline \multirow[b]{2}{*}{$\begin{array}{l}\text { Interval } \\
\text { days }\end{array}$} & \multirow{2}{*}{$\begin{array}{l}\text { Average } \\
\text { Soluble } \\
\text { Boron, } \\
\text { ppm }\end{array}$} & \multicolumn{3}{|c|}{$\mathrm{LHGR}^{(\mathrm{a})} \mathrm{kW} / \mathrm{ft}$} \\
\hline & & $13.20 \mathrm{~cm}$ & $27.70 \mathrm{~cm}$ & $165.22 \mathrm{~cm}$ \\
\hline 65.0 & 919 & 1.98 & 2.67 & 4.55 \\
\hline 5.5 & 911 & 2.15 & 2.91 & 4.80 \\
\hline 6.6 . & 896 & 2.20 & 2.98 & 4.80 \\
\hline 28.6 & 854 & 2.36 & 3.15 & 4.79 \\
\hline 31.2 & 784 & 254 & 3.36 & 4.72 \\
\hline 27.0 & 715 & 2.66 & 3.52 & 4.73 \\
\hline 22.7 & 655 & 2.77 & 3.63 & 4.71 \\
\hline 27.1 & 603 & 2.46 & 3.22 & 4.05 \\
\hline 55.2 & 521 & 2.81 & 3.64 & 4.34 \\
\hline 20.9 & 434 & 3.17 & 4.08 & 4.75 \\
\hline 41.9 & 356 & 3.32 & 4.24 & 4.79 \\
\hline 21.6 & 281 & 3.38 & 4.30 & 4.80 \\
\hline 27.6 & 226 & 3.21 & 4.04 & 4.49 \\
\hline 19.0 & 173 & 3.57 & 4.49 & 4.87 \\
\hline 61.2 & 79 & 3.05 & 3.79 & 4.00 \\
\hline $70^{(b)}$ & - & 0 & 0 & 0 \\
\hline
\end{tabular}

(a) At indicated axial locations from bottom of fuel.

(b) Cooling time to date of sample analyses (June 1987). 
Figure 3.1 Gamma Scan of Rod MKP109 with Sampling Locations Indicated

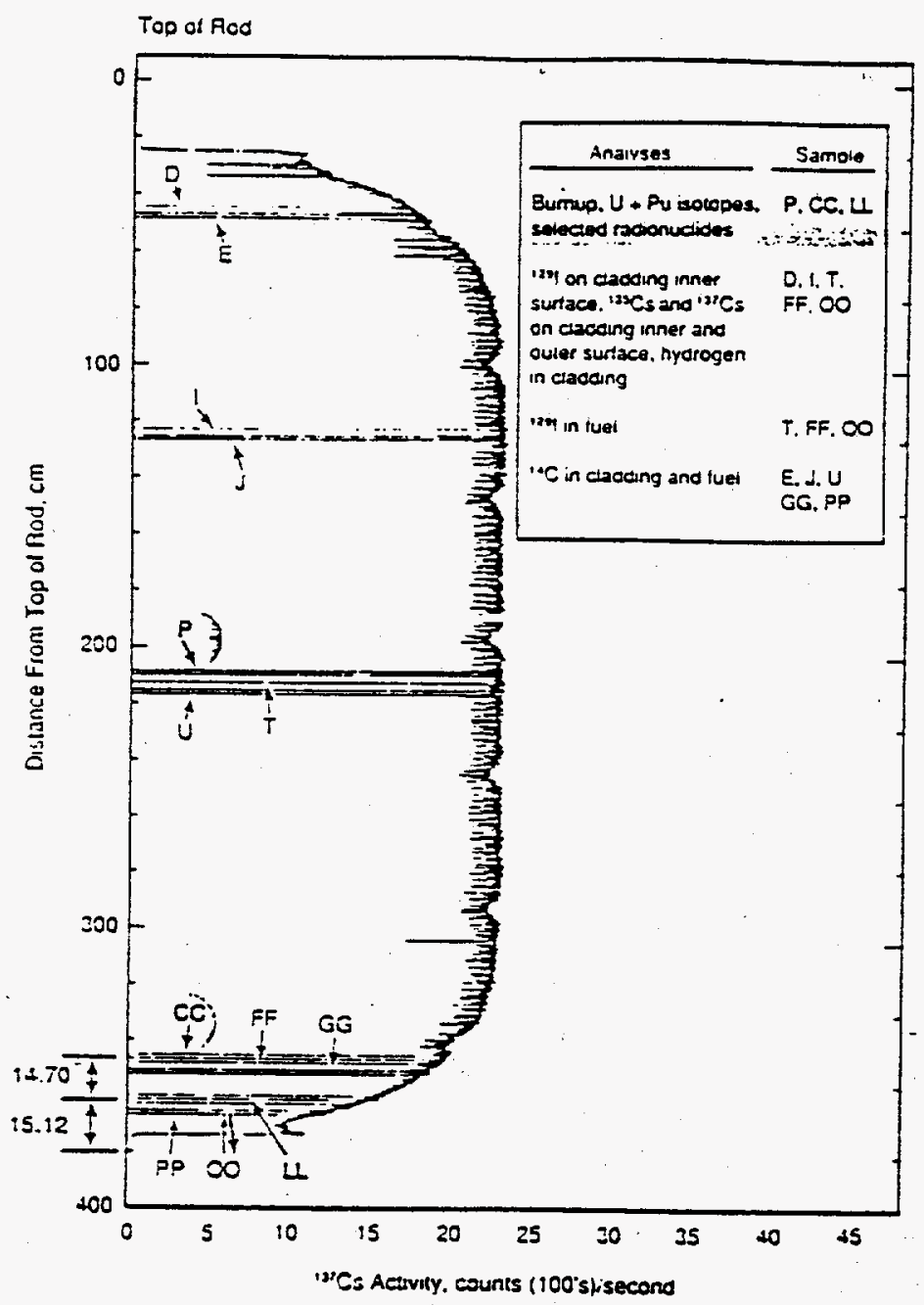

\subsection{Operating Data - Fuel Assembly D047, Rod MKP109}

Nominal operating conditions during each of the four cycles that the assembly was in the reactor are given in the table that follows. Calculated (Cunningham, 1984) temperatures of the fuel at each axial location sampled are also given in the table for each irradiation cycle.

For general information, the locations of fuel assembly D047 in the reactor during the four irradiation cycles are identified in this section also. Also identified in this section is the location of fuel rod MKP109 in the assembly. 
Table 3.4 Operating Data - Fuel Assembly D047, Rod MKP109

Cycle Number

Cycle Burnup, GWd/MTU

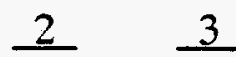

8.117

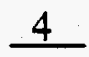

5

Nominal Coolant Temperature, ${ }^{\circ} \mathrm{C}^{(\mathrm{a})}$

Reactor Inlet

288

288

288

$344 \quad 344$

344

344

Nominal Coolant Pressure, psia ${ }^{(a)}$

Reactor Inlet

2250

2250

2250

2250

Reactor Outlet

N.A.

N.A.

N.A.

N.A.

Effective Fuel Temperature, ${ }^{\circ} \mathrm{C}^{(\mathrm{b})}$

$\begin{array}{lllll}13.02 \mathrm{~cm} & 556 & 577 & 502- & 436 \\ 27.70 \mathrm{~cm} & 667 & 654 & 520 & 439 \\ 165.22 \mathrm{~cm} & 724 & 685 & 521 & 474\end{array}$

(a) Design parameters per USAEC Docket No. 50-317 (Baltimore Gas and Electric Co., 1986). Personal communication on operating conditions give values of $284 \mathrm{C}$, $312 \mathrm{C}$, and 2247 psia.

(b) Time weighted volume averaged fuel temperatures at indicated axial locations from bottom of fuel as calculated using computer code GT2R2 (Cunningham, 1984). 
Figure 3.2 Location of Fuel Assembly in Reactor Core - Calvert Cliffs No. 1

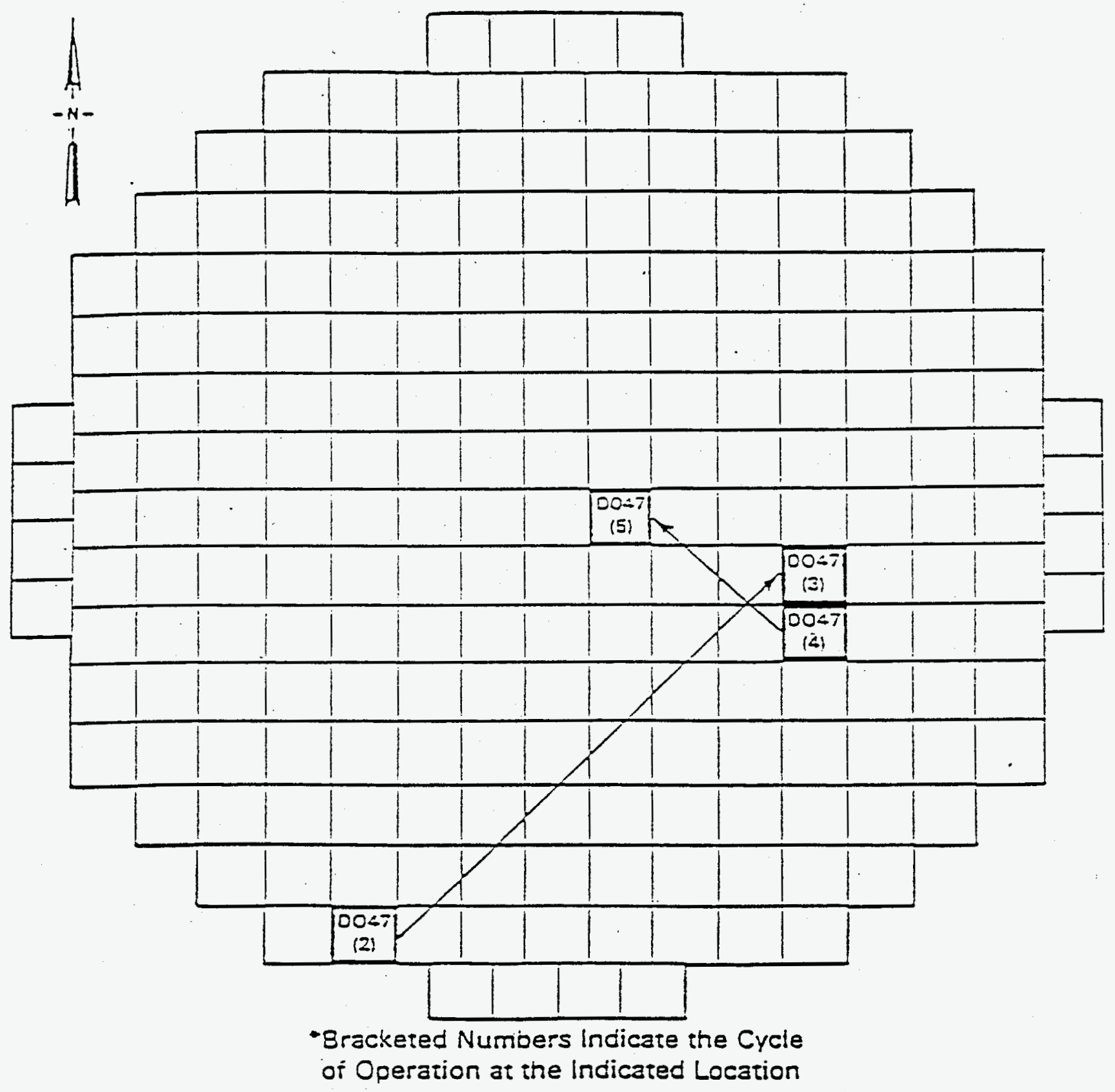


Figure 3.3 Location of Fuel Rod in Fuel Assembly Combustion Engineering Fuel Assembly D047

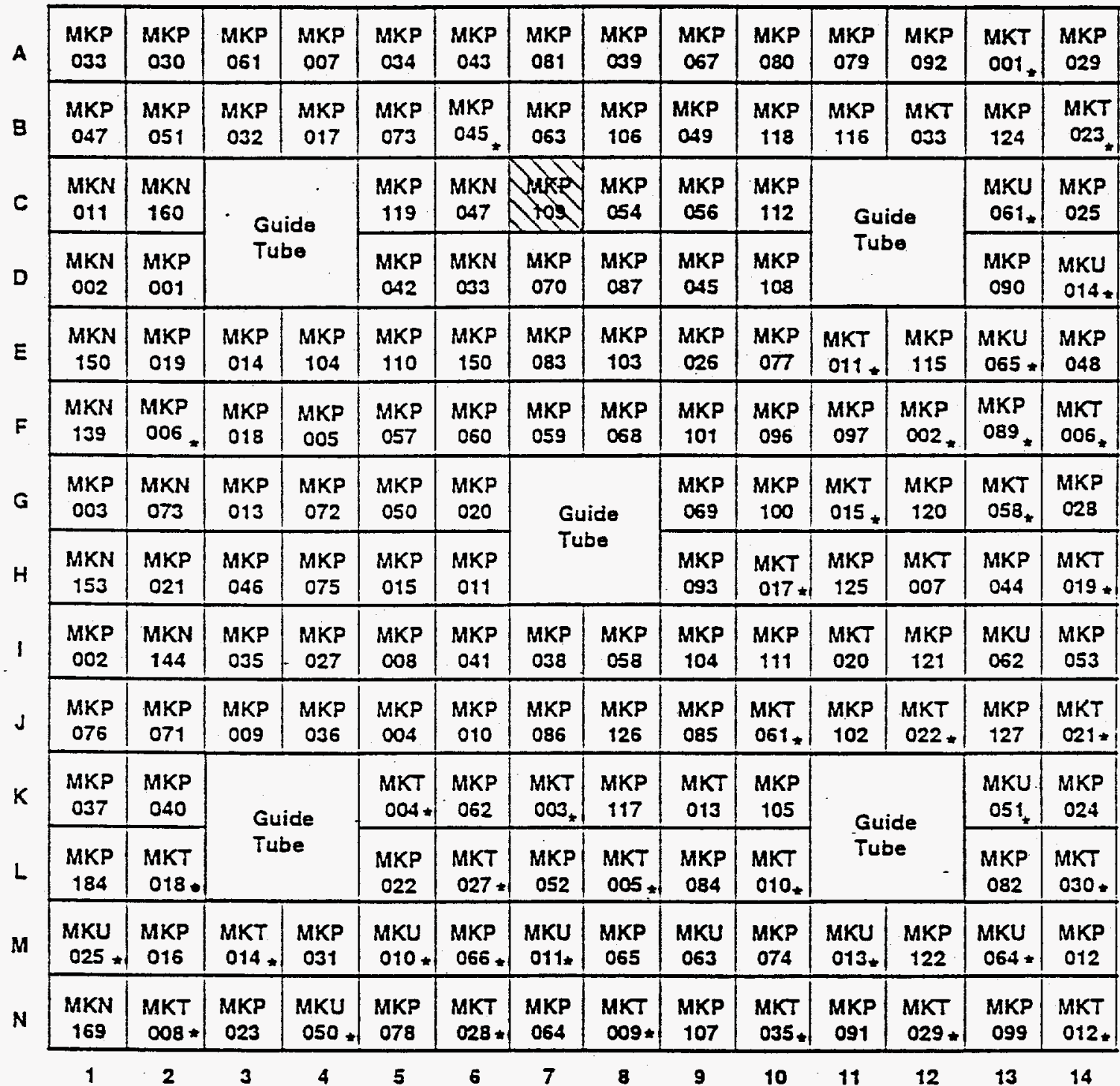

Note: Fuel rod serial numbers are presented as manufactured. Those indicated by * were replaced with special fuel rods for one or more cycles to study fuel and cladding structural properties (Ruzauskas, 1985). Rod MKP 045 was replaced after the fourth cycle of reactor operations with a $2.82 \mathrm{w} / \mathrm{o}^{235} \mathrm{U}$ enriched $\mathrm{UO}^{2}$ rod (AHS 077, EPRI Test Rod 38) containing a pore former to study in-reactor densification. 


\subsection{Conclusions and Recommendations}

The chemical composition of three spent PWR fuel samples have been analyzed to provide measured chemical compositions of interest in nuclear criticality calculations. The samples were taken at three different axial locations in a single fuel rod corresponding to measured burnups of $27.35 \mathrm{GWd} / \mathrm{MTU}, 37.12 \mathrm{GWd} / \mathrm{MTU}$ and $44.34 \mathrm{GWd} / \mathrm{MTU}$. One sample ( $27.35 \mathrm{GWd} / \mathrm{MTU})$ was analyzed by three different laboratories to establish estimated error limits for the strong neutron absorbing non-actinide nuclides. It is recommended that the other two samples be analyzed by at least a second laboratory to better establish error limits over the entire range of burnup currently of primary interest to storage and shipment of spent reactor fuel. It is also recommended that samples from a different spent fuel rod be similarly analyzed to provide improved confidence in the measurement data and future criticality calculations. These samples should also be analyzed for rhodium, which is one of the strong neutron absorbers in spent reactor fuel. The initial three samples analyzed were not analyzed for rhodium, in that no established method for rhodium analysis has been developed. Future work will incorporate an initiative to separate and analyze for rhodium. 


\subsection{Reférences}

American Society for Testing Materials. 1985. Standard Test Method for Atom Percent Fission in Uranium Fuel (Neodymium-148 Method). ASTM E 321-79.

Baltimore Gas and Electric Company. 1968. Application for Licenses for Calvert Cliffs Nuclear Power Plant Units 1 and 2, United States Atomic Energy Commission, Docket No. 50-317.

Combustion Engineering. 1986. Fuel Characterization Report for DOE Spent Fuel for Repository Studies. C-E Contract 12585, Combustion Engineering, Inc., Windsor, Connecticut.

Cunningham, M. E. and C. E. Beyer. 1984. GT2R2; An Updated Version of GAPCONTHERMAL-2. PNL-5178 (NUREG/CR-3907), Pacific Northwest Laboratory, Richland, Washington.

Guenther, R. J., D. E. Blahnik, U. P. Jenquin, J. E. Mendel, L. E. Thomas, and C. K. Thornhill. 1991. Characterization of Spent Fuel Approved Testing Material - ATM-104. PNL-5109-104, Pacific Northwest Laboratory, Richland, Washington.

Ruzauskas, E. J., A. M. Garde, S. R. Pati, L. V. Corsetti. 1985. Test Fuel Rod Iradiation in $14 \times 14$ Assemblies at Calvert Cliffs 1. Research Project 586-1, Task A, CE NPSD-289, Combustion Engineering, Inc., Windsor, Connecticut.

Sanders, T. L., R. M. Westfall, R. H. Jones. 1987. Feasibility and the Incentives for the Consideration of Spent Fuel Operating Histories in the Criticality Analysis of Spent Fuel Shipping Containers. SAND 87-0151, TTC-0713, Sandia National Laboratory, Albuquerque, New Mexico. 
APPENDIX A

Separation and Analyses of Lanthanide Component in Spent Fuel

A.1 


\section{APPENDIX A \\ Separation and Analyses of Lanthanide Component in Spent Fuel}

Except for the lanthanides, the chemical assay data presented in Table 3.2 of this report were obtained using established and well-documented procedures as identified in Section 2.0, Radiochemical Procedures. The procedure used in obtaining the data presented in Table 3.2 for the lanthanide elements consisted of a combination of existing measurement techniques. Although each of the measurement methods used in the lanthanide analyses are currently accepted analytical techniques, their adaptation to analyzing spent reactor fuel are briefly described in this appendix.

Since spent reactor fuel consists of a multitude of chemical elements, the approach taken in analyzing for lanthanide isotopes was to first dissolve a fuel sample in nitric acid, chemically separate the lanthanide component from the spent fuel sample, and analyze this component for the lanthanide isotopes of interest to nuclear criticality by mass spectrometry measurements. The isotopes of interest are strong neutron absorbers and consist of nuclides having mass numbers of 147 (samarium), 150 (samarium and neodymium), 151 (samarium and europium), and 155 (europium and gadolinium). To permit quantifying the results, the mass spectrometry of the neodymium isotopes were determined by the ANSI/ASTM Standard Test Method as indicated in Section 2 of the report.

Following dissolution of the fuel in nitric acid, extraction chromatography and ion exchange are used to isolate the lanthanide fission products from the spent fuel samples. Aliquots, containing up to $10 \mathrm{mg}$ of uranium, are taken from each fuel sample for lanthanide element separation. Uranium and tetravalent actinides are separated from each solution sample by passing a sample through a U/TEVA-Spec* resin column (* registered trademark of EIChroM Industries). The uranium and tetravalent actinides are retained on the resins. The lanthanides and americium pass through the column into a RE-Spec* resin column where the lanthanides (rare earths) and the americium are retained (* registered trademark of EIChroM Industries). Other fission products are mostly washed to waste. The lanthanides and americium are eluted off the RE-Spec* column, chemically adjusted and evaporated to dryness to remove residual organics and chlorides. The dry sample is dissolved in $\mathrm{NH}_{4} \mathrm{SCN}$-formic acid and passed through a TEVA-Spec* column where the americium is retained ( ${ }^{*}$ registered trademark of EIChroM Industries). The solution sample is then passed through a cation exchange column to remove excess $\mathrm{NH}_{4} \mathrm{SCN}$ and to separate the lanthanide elements of interest from most of the other lanthanides. Lanthanide recovery is followed through each step by monitoring the ${ }^{154,155} \mathrm{Eu}$ activity. 
The U/TEVA-Spec*, RE-Spec*, and associated pre-filter columns are operated in serial configuration with the U/TEVA-Spec column on top, the pre-filter column in the middle, and the RE-Spec* column on the bottom. All three columns are prewashed with nominally $2 \mathrm{~mL}$ of water and $5 \mathrm{~mL}$ of $3 \mathrm{M} \mathrm{HNO}_{3}$. Samples are loaded on the top column, followed by five $1 \mathrm{~mL}$ washes of $3 \mathrm{M} \mathrm{HNO}_{3}$. As stated previously, the U/TEVA-Spec* retains the $U$ and tetravalent actinides. (The resin capacity is about 10 $\mathrm{mg}$ of $\mathrm{U}$ and can be visually monitored by the yellow color of the absorbed $U$ on the column.) The pre-filter column collects any extractant (resins) which may elute from the U/TEVA-Spec* column. The U/TEVA-Spec ${ }^{*}$ and pre-filter columns are discarded along with all the effluents (washes).

The RE-Spec* column is converted to the chloride form and residual, nonlanthanide fission products are removed by sequentially washing the column with $10 \mathrm{~mL}$ of $1 \mathrm{M} \mathrm{HNO}_{3}-0.01 \mathrm{M}$ ammoniumbioxalate, $10 \mathrm{~mL}$ of $1 \mathrm{M} \mathrm{HNO}_{3}$, and $6 \mathrm{~mL}$ of $9 \mathrm{M}$ $\mathrm{HCl}$. The effluents are discarded. The lanthanides and Am retained on the RE-Spec* column are eluted from the column with $20 \mathrm{~mL}$ of $4 \mathrm{M} \mathrm{HCl}$, then evaporated to dryness and converted to wet ash with $\mathrm{HNO}_{3}-\mathrm{H}_{2} \mathrm{O}_{2}$ and aqua regia to destroy any traces of organics. Following conversion to $\mathrm{HNO}_{3}$, the sample is evaporated just to dryness. The sample is dissolved in $1 \mathrm{~mL}$ of $2 \mathrm{M} \mathrm{NH}_{4} \mathrm{SCN}-0.1 \mathrm{M}$ formic acid, covered tightly and allowed to stand to assure the dissolution of the sample.

A TEVA-Spec* column, a pre-filter column and a cation exchange column are operated in series to separate Am from the sample and to obtain a purified lanthanide sample containing the elements of interest (Ce through Gd). The TEVA-Spec* column is prepared by washing the column with $3 \mathrm{~mL}$ of water followed by $5 \mathrm{~mL}$ of $2 \mathrm{M}$ $\mathrm{NH}_{4} \mathrm{SCN}-0.1 \mathrm{M}$ formic acid. The pre-filter column is prepared as stated above. The cation exchange column consists of a 2 mL Dowex $50 \mathrm{X} 4$ 100-200 mesh column that has been washed with $5 \mathrm{~mL}$ of water followed by $5 \mathrm{~mL}$ of $1 \mathrm{M} \mathrm{NH}_{4} \mathrm{SCN}-0.1 \mathrm{M}$ formic acid ( ${ }^{*}$ Dowex is a registered trademark of Dow Chemical Company). The columns are set up in serial configuration with the TEVA-Spec* column on top, the pre-filter column in the middles and the cation exchange column on the bottom. The Am-lanthanide solution sample is transferred to the top column. As in the previous steps, the activity of ${ }^{154,155} \mathrm{Eu}$ is used to follow the Am-lanthanide separation. The columns are washed with $13 \mathrm{~mL}$ of $1 \mathrm{M} \mathrm{NH}_{4} \mathrm{SCN}-0.1 \mathrm{M}$ formic acid and discarded along with all the effluents (the TEVA-Spec* column retains the Am). The Dowex*50X4 column washed with 10 $\mathrm{mL}$ of $0.4 \mathrm{M} \mathrm{HCl}$ and the effluent is discarded. The lanthanides are eluted from the column with $10 \mathrm{~mL}$ of $6 \mathrm{M} \mathrm{HCl}$. The solution is evaporated to dryness, wet ash with $\mathrm{HNO}_{3}$ and then heated gently over a burner flame to drive off volatile salts. The isotopic composition of the purified sample is then determined by standard inductively coupled plasma mass spectrometry measurements. 


\section{APPENDIX B}

Estimated Uncertainties in Spent Fuel Sample Analyses

B. 1 


\section{APPENDIX B}

\section{Estimated Uncertainties in Spent Fuel Sample Analyses}

Uncertainties are given in Section 2.0, Radiochemical Procedures, for all of the analyses except for the lanthanide elements. The uncertainties given in Section 2.0 are for relatively common procedures which have had sufficient use and comparison against standards to permit estimating the uncertainties associated with the respective analysis. However, the analytical procedure used to analyze the spent fuel samples for lanthanide nuclides was developed specifically for the spent fuel assays presented in this report. As indicated in Appendix A, recovery of the lanthanide component in spent fuel can be followed closely by monitoring the 154,155 europium activity. To further reduce the dependency of the results on total lanthanide recovery, the isotopic compositions are determined by mass spectrometry relative to ${ }^{143} \mathrm{Nd}$ and ${ }^{145} \mathrm{Nd}$ for which absolute values existed. Therefore, it was concluded that errors associated with complete lanthanide recovery were negligibly small compared to those incurred in analyzing the mass spectrometry measurements. To assess the reproducibility of the mass spectrometry data portions of the lanthanide component of spent fuel sample 87-81 were analyzed by two laboratories other than the Pacific Northwest Laboratory (PNL). They were the Los Alamos National Laboratory (LANL), Los Alamos, New Mexico and the Khlopin Radium Institute (KRI), St. Petersburg, Russia. Both PNL and LANL analyzed the lanthanide sample by Inductively Coupled Plasma-Mass Spectrometry (ICP-MS). The KRI employed several techniques in analyzing the lanthanide sample including Secondary Ion Mass Spectrometry (SIMS). However, the KRI suggested that the SIMS - data be considered indicative of methods application, and that the Sm and Gd results should be doubted (see Appendix E). Consequently, the SIMS data were not considered in comparing the measurement results obtained by the three laboratories. A copy of the LANL and PNL measurement data, as well as the KRI report, is included in Appendices $\mathrm{C}, \mathrm{D}$, and $\mathrm{E}$, respectively.

Basically, the approach taken by KRI in analyzing the sample provided by PNL was to chemically separate the lanthanides into individual elements and then with the use of spikes and laser luminescence perform mass spectrometry measurements to obtain absolute quantity values for each of the lanthanide isotopes. All but about $30 \mathrm{ng}$ of the sample sent to the KRI was dissolved in $0.1 \mathrm{M}$ nitric acid and divided between three aliquots. Laser luminescence measurements were performed on one of these solutions sample ( $0.19735 \mathrm{~g}$ of solution) and compared to measurements on standard solutions containing known amount of Sm and Eu to obtain absolute quantities for Sm and $\mathrm{Eu}$ in the sample. These absolute quantities were multiplied by the isotopic abundance figures obtained later from mass spectrometry measurements to obtain the isotopic values. 
One of the solution samples (1.6490g of solution) was spiked with known quantities of Nd-142 and Gd-156. After successive coprecipitation on fluoride and hydroxide of lanthanum and dissolution in 0.001M EDTA, the solution was separated into pure fractions of individual elements by electrophoresis separation on to Whatman-31 paper. Zones were identified on the paper strip by gamma measurements and sample were prepared for mass spectrometry measurements to obtain isotopic abundance figures for $\mathrm{Nd}$ and $\mathrm{Gd}$ (as well as the other lanthanides). These were then used with known (spiked) values for $\mathrm{Nd}-142$ and Gd-156 to obtain the isotopic values for $\mathrm{Nd}$ and $\mathrm{Gd}$. 
The third aliquot sample (unspiked) was electrosphoresisly separated into pure fractions also. Mass spectrometry measurements were performed on the zones as in the spike sample above to obtain isotopic abundance values for the lanthanide elements. These abundance figures were used with the laser luminescence quantitative values for $\mathrm{Sm}$ and Eu to obtain the isotopic values for $\mathrm{Sm}$ and Eu. About $28.56 \mathrm{ng}$ of sample was removed from the sample shipped and prepared for Secondary Ion Mass Spectrometry (SIMS) measurements. As indicated previously, the SIMS data are suspect and are not considered in the data comparisons that follow.

Since the PNL and LANL results are based on mass spectrometry measurements of the total lanthanide sample, these data are in terms of mass numbers relative to an arbitrarily selected mass number. The KRI data are in terms of isotope concentrations because they separated the lanthanide sample into individual elements prior to mass spectrometry measurements. To compare the data and arrive at estimated error limits, the KRI isotopic values having a common mass number have been combined to obtain a value for that mass number (see Appendix $C$ for the sample isotopic concentrations).

As indicated in Section 2 of the report, the neodymium isotopes were determined by an approved ANSI/ASTM standard measurement method (ANSI/ASTM Standard Test Method E321-79). Since this procedure is a nationally accepted method of analyses, the neodymium values reported in Section 3 of the report are considered the most reliable of the lanthanides. Consequently, the data from each of the three laboratories are compared relative to ${ }^{143} \mathrm{Nd}$ and to ${ }^{145} \mathrm{Nd}$ which are considered to be the better neodymium data. The measurement results obtained from the three laboratories are - summarized in the following two tables for comparison purposes relative to ${ }^{143} \mathrm{Nd}$ and to ${ }^{145} \mathrm{Nd}$. 
Table B.1 Comparison of Sample 87-81 Lanthanide Analyses Relative to ${ }^{143} \mathrm{Nd}$

\begin{tabular}{|c|c|c|c|c|}
\hline \multirow[b]{2}{*}{ Mass Number } & \multicolumn{3}{|c|}{ M-XXX Relative to M-143 } & \multirow[b]{2}{*}{ Average \pm 10} \\
\hline & PNL & $\mathbf{K R I}$ & LANL & \\
\hline 143 & 1.000 & 1.000 & 1.000 & 1.000 \\
\hline 144 & 1.54 & 1.54 & 1.54 & $154 \pm 0.0$ \\
\hline 145 & 0.826 & 0.821 & 0.820 & $0.822 \pm 0.003$ \\
\hline 146 & 0.801 & 0.799 & 0.795 & $0.798 \pm 0.003$ \\
\hline 147 & 0.352 & 0.327 & 0.352 & $0.344 \pm 0.014$ \\
\hline 148 & 0.588 & 0.571 & 0.574 & $0.578 \pm 0.009$ \\
\hline 149 & 0.0046 & 0.0038 & 0.0032 & $0.0037 \pm 0.0007$ \\
\hline 150 & 0.517 & 0.500 & 0.516 & $0.511 \pm 0.009$ \\
\hline 151 & 0.014 & 0.013 & 0.014 & $0.014 \pm 0.001$ \\
\hline 152 & 0.134 & 0.129 & 0.134 & $0.132 \pm 0.003$ \\
\hline 153 & 0.121 & 0.121 & 0.124 & $0.122 \pm 0.002$ \\
\hline 154 & 0.063 & 0.071 & 0.063 & $0.066 \pm 0.005$ \\
\hline 155 & 0.0068 & 0.0103 & $0.0295^{(a)}$ & $0.0086 \pm 0.0025$ \\
\hline 156 & 0.070 & 0.091 & 0.098 & $0.086 \pm 0.014$ \\
\hline 157 & 0.0007 & 0.0007 & - & $0.0007 \pm 0.0$ \\
\hline 158 & 0.0145 & 0.0198 & - & $0.0172 \pm 0.0037$ \\
\hline 159 & 0.0042 & - & - & - \\
\hline 160 & 0.0003 & 0.0021 & - & $0.0012 \pm 0.0013$ \\
\hline
\end{tabular}

a) Not included in average.

Table B.2 Comparison of Sample 87-81 Lanthanide Analyses Relative to ${ }^{143} \mathrm{Nd}$

\begin{tabular}{c} 
Mass Number \\
\hline 143 \\
144 \\
145 \\
146 \\
147 \\
148 \\
149 \\
150 \\
151 \\
152 \\
153 \\
154 \\
155 \\
156 \\
157 \\
158 \\
159 \\
160
\end{tabular}

\begin{tabular}{l} 
PNL \\
\hline 1.210 \\
1.859 \\
1.000 \\
0.970 \\
0.426 \\
0.711 \\
0.0056 \\
0.625 \\
0.0175 \\
0.162 \\
0.146 \\
0.076 \\
0.0083 \\
0.085 \\
0.0009 \\
0.0176 \\
0.0051 \\
0.0004
\end{tabular}

M.XXX Relative to M-143

a) Not included in average.

\begin{tabular}{lll}
$\mathbf{K R I}$ & \multicolumn{1}{c}{ LANL } \\
\cline { 3 - 3 } 1.218 & 1.220 \\
1.882 & 1.880 \\
1.000 & 1.000 \\
0.974 & 0.970 \\
0.398 & 0.429 \\
0.696 & 0.700 \\
0.0047 & 0.0039 \\
0.609 & 0.630 \\
0.0159 & 0.0165 \\
0.157 & 0.163 \\
0.147 & 0.151 \\
0.087 & 0.077 \\
0.0126 & $0.036^{(\mathbf{a})}$ \\
0.110 & 0.119 \\
0.0008 & - \\
0.0241 & - \\
- & - \\
0.0025 & - \\
&
\end{tabular}

\begin{tabular}{l} 
Average $\pm 1 \sigma$ \\
\hline $1.216 \pm 0.005$ \\
$1.874 \pm 0.013$ \\
1.000 \\
$0.971 \pm 0.002$ \\
$0.418 \pm 0.017$ \\
$0.702 \pm 0.008$ \\
$0.0047 \pm 0.0008$ \\
$0.621 \pm 0.011$ \\
$0.0166 \pm 0.0008$ \\
$0.161 \pm 0.003$ \\
$0.148 \pm 0.003$ \\
$0.080 \pm 0.006$ \\
$0.0104 \pm 0.0030$ \\
$0.105 \pm 0.018$ \\
$0.0085 \pm 0.0001$ \\
$0.0208 \pm 0.0046$ \\
- \\
$0.0014 \pm 0.0015$
\end{tabular}


The results obtained by the three laboratories indicate that analytical results for the lanthanides of interest to nuclear criticality can be expected to be within the following one sigma limits:

M-155 29\%

Eu-153 2\%

Sm-152 3\%

Sm-151 7\%

$\mathrm{Sm}-150-2 \%$

Sm-149 18\%

$\mathrm{Sm}-147 \sim 4 \%$

Nd- $145<1 \%$

Nd- $143<1 \%$ 
APPENDIX C

Pacific Northwest Laboratories Mass Spectrometry Measurement Data

C.1 


\section{APPENDIX C \\ Pacific Northwest Laboratories Mass Spectrometry Measurement Data}

The lanthanide component in each of the three spent fuel sample, 87-81, 87-72, and 8763 were analyzed by Inductively Coupled Plasma-Mass Spectrometry in accordance with PNL-ALO-280, RO, dated 9/26/90. The measurement results obtained are presented in this appendix. 


\begin{tabular}{|c|c|c|c|c|c|}
\hline & A & B & $\mathrm{C}$ & DI & $F$ \\
\hline 1 & & \multicolumn{4}{|c|}{ Bierman REE Fission Product Analysis } \\
\hline 2 & & \multicolumn{3}{|c|}{ Oct. 16,1992} & \\
\hline 3 & & \multicolumn{3}{|c|}{ S.AMUPLE $\Omega \cdot P-81$} & \\
\hline 4 & & $a m u$ & MEAN & 1 Corr cps/amu & Norm to $144^{\circ}$ \\
\hline 5 & & & cos/amu & & \\
\hline 6 & & & & & \\
\hline 7 & & 139 & 206369 & 2278201 & 0.99738 \\
\hline 8 & & 1401 & 2390961 & $242912 !$ & 1.06345 \\
\hline 9 & & 141 & 2086381 & 2086281 & 0.91336 \\
\hline 10 & & 1421 & 208869 & 2073761 & 0.90787 \\
\hline 11 & & 143 & 150830 & 1486941 & 0.65097 \\
\hline 12 & & 144 & 233377 & 2284201 & 1.00000 \\
\hline 13 & & $145 !$ & 1254731 & 122884 & 0.53797 \\
\hline 14 & & 1461 & 122519 & 1191401 & 0.52158 \\
\hline 15 & & 147 & 53391 & $52372 !$ & 0.22928 \\
\hline 16 & & 1481 & 882961 & 873681 & 0.38249 \\
\hline 17 & & 149 & 6981 & 687 & 0.00301 \\
\hline 18 & & 150 & 76366 & 768531 & 0.33645 \\
\hline 19 & & 1511 & 2130 & 21521 & 0.00942 \\
\hline 20 & & 152 & 195001 & 199481 & 0.08733 \\
\hline 21 & & 153 & 174551 & 180041 & 0.07882 \\
\hline 22 & & 154 & 89231 & 93401 & 0.04089 \\
\hline 23 & & 155 & 17931 & 1019 & 0.00446 \\
\hline 24 & & 156 & 10639 & 104561 & 0.04578 \\
\hline 25 & & 157 & 945 & 1101 & 0.00048 \\
\hline 26 & & 158 & 27831 & 21591 & 0.00945 \\
\hline 27 & & 159 & 1166 & 6251 & 0.00274 \\
\hline 28 & & 1601 & 9861 & 481 & 0.00021 \\
\hline 29 & & 161 & 546 & $35 i$ & 0.00015 \\
\hline 30 & & 162 & 5421 & 491 & 0.00021 \\
\hline 31 & & 163 & 1731 & -611 & .0 .00026 \\
\hline 32 & & 1641 & 3291 & $.42 !$ & -0.00018 \\
\hline
\end{tabular}


ree fps final

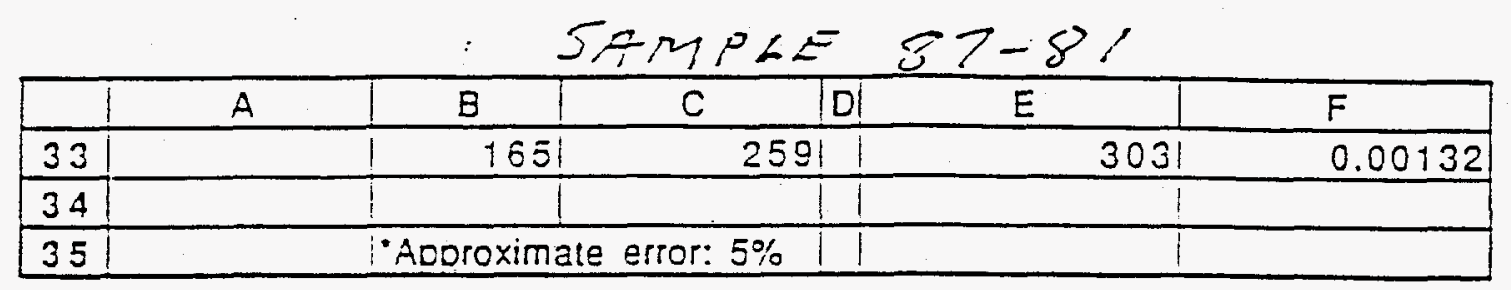




\begin{tabular}{|c|c|c|c|c|c|c|c|c|}
\hline amu & $87-72$ & $87-63$ & Remix La & Remix & Oxide Corr & Oxide Corr & BLANK AVE & \\
\hline & Norm; Ave & Norm; Ave & Run 1 & Run 1 & Soln & Faclor & & \\
\hline & & & & & & & & \\
\hline 139 & 80219 & 71557 & 143090 & 317 & 665352 & & 15 & \\
\hline 140 & 93359 & 79441 & 202328 & 195841 & 650297 & & 15 & \\
\hline 141 & 81184 & 68755 & 106249 & 103519 & 746498 & & 15 & \\
\hline 142 & 81067 & 69897 & 132554 & 132192 & 277841 & & 15 & \\
\hline 143 & 50884 & 37733 & 47542 & 48437 & 87773 & & 15 & \\
\hline 144 & 95528 & 82549 & 97782 & 97307 & 173131 & & 15 & \\
\hline 145 & 45929 & 36814 & 33247 & 32733 & 61434 & & 15 & \\
\hline 146 & 48114 & 41850 & 68274 & 68865 & 125257 & & 15 & \\
\hline 147 & 17634 & 12926 & 9451 & 9651 & 16 & & 15 & \\
\hline 148 & 35999 & 31049 & 30630 & 30716 & 41954 & & 15 & \\
\hline 149 & 222 & 237 & 9335 & 9064 & 109 & & 15 & \\
\hline 150 & 30054 & 26861 & 28258 & 28258 & 42116 & & 15 & \\
\hline 151 & 640 & 473 & 4307 & 4263 & 18 & & 15 & \\
\hline 152 & 6947 & 5656 & 17411 & 17372 & 28 & & 15 & \\
\hline 153 & 7246 & 6838 & 4718 & 4650 & 32 & & 15 & \\
\hline 154 & 3999 & 3920 & 15090 & 14793 & 54 & & 15 & \\
\hline 155 & 893 & 831 & 1864 & 1278 & 3416 & 0.00513 & 15 & \\
\hline 156 & 6725 & 8032 & 2766 & 2681 & 4698 & 0.00723 & 15 & \\
\hline 157 & 455 & 389 & 2185 & 2035 & 4648 & 0.00623 & 15 & \\
\hline 158 & 1536 & 1677 & 2847 & $2 \overline{972}$ & 2132 & 0.00768 & 15 & \\
\hline 159 & 464 & 406 & 208 & 291 & 746 & 0.00850 & 15 & \\
\hline 160 & 520 & 438 & 2387 & 2551 & 978 & 0.00565 & 15 & \\
\hline 161 & 265 & 198 & 217 & 175 & 491 & 0.00800 & 15 & \\
\hline 162 & 297 & 243 & 338 & 316 & 670 & 0.00535 & 15 & \\
\hline 163 & 88 & 46 & 46 & 49 & 90 & 0.00600 & 15 & \\
\hline 164 & 163 & 122 & 155 & 122 & 267 & 0.00636 & 15 & \\
\hline 165 & 37 & 28 & 35 & 28 & 74 & 0.00600 & 15 & \\
\hline
\end{tabular}




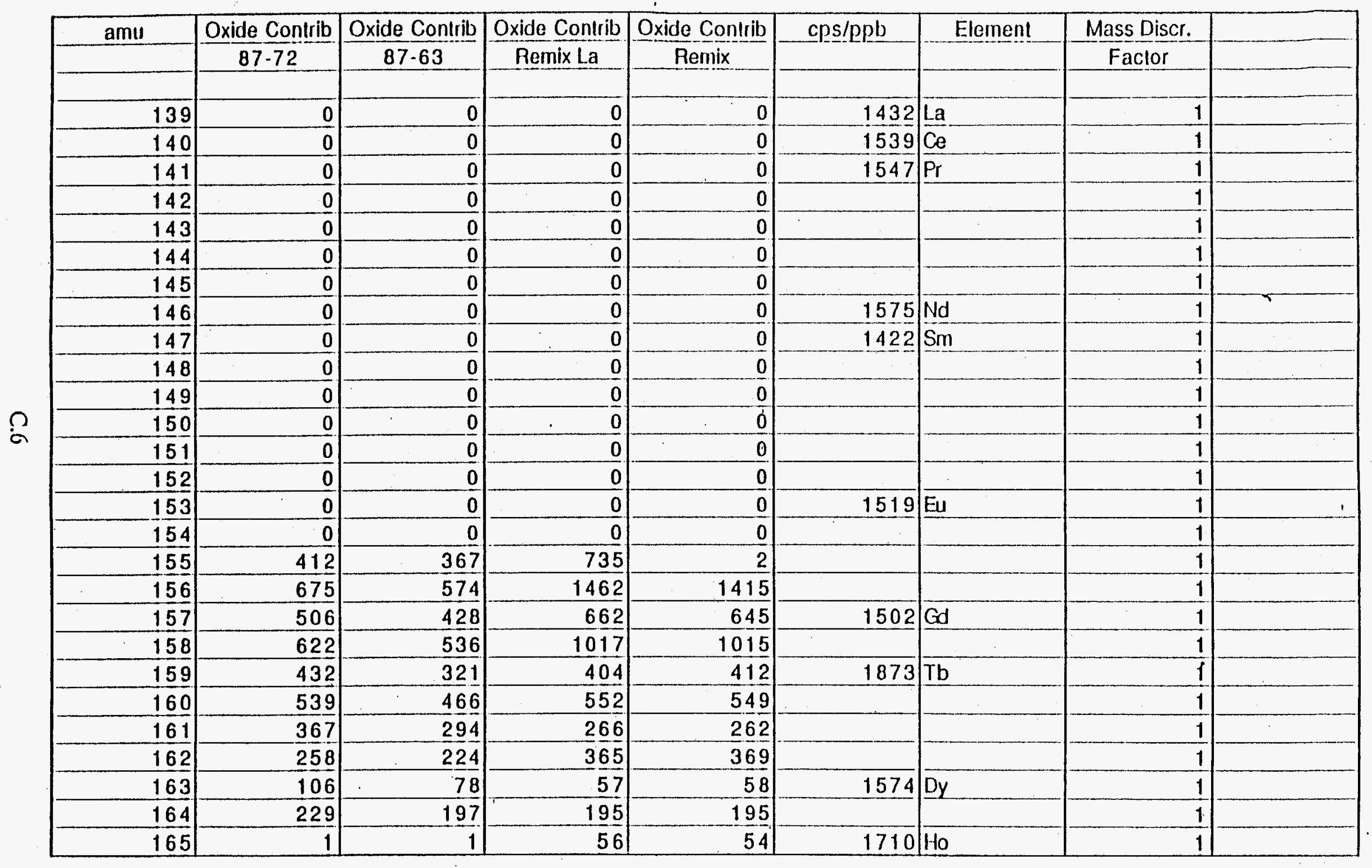




\begin{tabular}{|c|c|c|c|c|}
\hline amu & Corr cps/amu & Corr cps/amu & Corr cps/amu & Corr cps/amu \\
\hline & $87 \cdot 72$ & 87.63 & Remix La & Aemix \\
\hline 139 & 80204 & 71542 & 143075 & 302 \\
\hline 140 & 93344 & 79426 & 202313 & 195826 \\
\hline 141 & 81169 & 68740 & 106234 & 103504 \\
\hline 142 & 81052 & 69882 & 132539 & 132177 \\
\hline 143 & 50869 & 37718 & 47527 & 48422 \\
\hline 144 & 95513 & 82534 & 97767 & 97292 \\
\hline 145 & 45914 & 36799 & 33232 & 32718 \\
\hline 146 & 48099 & 41835 & 68259 & 68850 \\
\hline 147 & 17619 & 12911 & 9436 & 9636 \\
\hline 148 & 35984 & 31034 & 30615 & 30701 \\
\hline 149 & 207 & 222 & 9320 & 9049 \\
\hline 150 & 30039 & 26846 & 28243 & 28243 \\
\hline 151 & 625 & 458 & 4292 & 4248 \\
\hline 152 & 6932 & 5641 & 17396 & 17357 \\
\hline 153 & 7231 & 6823 & 4703 & 4635 \\
\hline 154 & 3984 & 3905 & 15075 & 14778 \\
\hline 155 & 466 & 448 & 1115 & 1262 \\
\hline 156 & 6035 & 7443 & 1289 & 1251 \\
\hline 157 & -65 & -54 & 1508 & 1375 \\
\hline 158 & 899 & 1126 & 1814 & 1943 \\
\hline 159 & 17 & 70 & .211 & -136 \\
\hline 160 & -34 & -43 & 1820 & 1986 \\
\hline 161 & -117 & -111 & -64 & -102 \\
\hline 162 & 24 & 4 & -43 & -67 \\
\hline 163 & -33 & -46 & -25 & -24 \\
\hline 164 & -81 & -90 & -55 & -88 \\
\hline 165 & 20 & 11 & -36 & -41 \\
\hline
\end{tabular}


APPENDIX D

Los Alamos National Laboratory Mass Spectrometry Measurement Data

D.1 


\section{APPENDIX D}

Los Alamos National Laboratorv Mass Spectrometry Measurement Data

The lanthanide component in spent fuel sample $87-81$ was analyzed by Inductively Coupled Plasma-Mass Spectrometry as described in this appendix along with measurement results. The lanthanide sample analyzed by LANL was taken from the larger sample prepared as described in Appendix A and thus was identical to the sample analyzed by PNL (see Appendix C). 
Los Almos

Los Alamos National Laboratory

Los Alamos, New Mexico 87545

Chemical and Laser Sciences Division

Dr. Robert Strebin

Buttelle Memorial Instiwte

Pacilic Northwest Laboratory

P.O. Box 999, MS PS-08

Richiand, WA 99352

March 9,1993

Deur Bob,

Enclosed are the linal results for the rare curth fission product sample. Included is a procedure describing how the samples were run, and several ligures which give the raw datid and show the calculations. Let me know il you need any other intonnation.

cropies: CLS-1 Groun OHIice
CRM-4, MS A150

cropies: CLS-1 Group Ollice
CRM-4, MS A150

Sincercly,

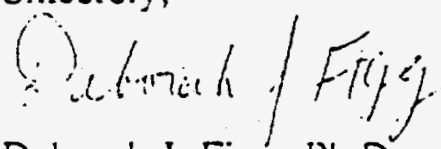

Deburah J. Figg, Ph.D.

Siall Mernber

Analytical Chemistry 
PROCEDURE FOR RUNNING RARE EARTH FISSION PRODUCTS

\section{1) Instrument}

The instrument used was a VG PlasmaQuad II. Prior to running the rare earth fission product sample all ICP glassware (spray chamber, nebulizer, and torch) were cleaned in aqua regia and all the peristaltic tubing was changed since it was necessary to recycle the sample given its quantity. The instrument was always given at least 30 minutes to warm up. Following this period, the resolution and mass calibration were checked and the ion optics were tuned for maximum signal at $\mathrm{m} / z=153$ (Eu) using a $100 \mathrm{ppb}$ solution of natural abundance $\mathrm{La}, \mathrm{Ce}, \mathrm{Pr}, \mathrm{Nd}, \mathrm{Sm}$, and EL. The typical ion optic settings (in potentiometer turns) were as follows.
Extractor: 1.0
LI: 6.25
L3: 5.99
Collector: 6.0
$L 2: 3.12$
L4: 7.50
Front plate: 2.88
Pole bias: 5.75

The counts for $\mathrm{La}^{2}+, \mathrm{La}^{+}$, and $\mathrm{LaO}+$ were measured in order to determine the percentage of $\mathrm{La}^{2}+$ to $\mathrm{La}^{+}$and $\mathrm{LaO}^{+}$to $\mathrm{La}^{+}$. The nebulizer gas flow was adjusted so that these percentages were $2 \%$ or less. The gas flow rates $(\mathrm{L} / \mathrm{min}$.) were as follows.
Coolant: 16
Auxiliary:
0.60
Nebuiizer: 0.731

The incident plasma if power was $1.3 \mathrm{~kW}$ with a reflected power of less than $5 \mathrm{~W}$. The average signal was $1.4 \times 10^{6} \mathrm{cps} / \mathrm{ppm} \mathrm{Eu}$.

2) Dissolution of Sample

A $1 \mu \mathrm{g}$ sample was provided to us by Bob Strubing of PNL. We did not confirm the weight of the sample here. $0.250 \mathrm{ml}$ of concentrated $\mathrm{HNO}_{3}$ was added to the sample vial, causing an immediate reaction with the sample. The acid was swished around the vial and then the contents were poured into a larger vial. Another $0.250 \mathrm{mi}$ aliquot of concentrated $\mathrm{HNO}_{3}$ was added to the original sample vial, swished around and then poured into the larger vial. The original sample vial was then rinsed into the larger vial several times with $2 \% \mathrm{HNO}_{3}$. The volume of the larger vial was taken to $25.0 \mathrm{ml}$. This was the final solution on which the measurements were made.

\section{3) ICP-MS Measurements}

The scan parameters used for all sample, blank, and standard runs were as follows.

$$
\begin{aligned}
& \# \text { of channels }=1024 \\
& \text { scans }=600 \\
& \text { dwell time }=640 \mu \mathrm{s}
\end{aligned}
$$


scan range $=134.9-176.5 \mathrm{amu}$

The sample was analyzed 1 time on day 1,3 times on day 2 , and 3 times on day 3 . The procedure for each day was as follows, blank, standard, rare earth sample, blank. When the sample was analyzed 3 times in one day the 3 analyses were performed using a single procedure, that is, $3 \times$ blank, $3 \times$ standard, $3 \times$ rare earth sample, $3 \times$ blank. The blanks that were run first in a procedure were used for blank subtraction (see figure 1 for blank data). The last blanks in the procedure were not used in the calculations, instead only for a qualitative check. The standard, ran second in the procedure, was a $10 \mathrm{ppb}$ solution containing natural abundant $L a, C e$, $\mathrm{Pr}, \mathrm{Nd}, \mathrm{Sm}$, and Eu. After all the data acquisition it was decided to rerun the standard at $100 \mathrm{ppb}$ in order to obtain a more precise mass bias measurement. The 100 ppb standard was run 6 times, 3 times on 2 different days. See figure 2 for standard data.

Between different sample types $2 \% \mathrm{HNO}_{3}$ solution was rinsed through the instrument until the counts at Eu 153 were less than 50 cps, it was then allowed to rinse for 2 additional minutes. After placing the sipper in a solution, a 2 minute uptake time was allowed prior to data acquisition.

Since the rare earth sample was recycled during analysis, care was taken so as to minimize dilution from the $2 \% \mathrm{HNO}_{3}$ rinse solution. Before and after the sample was introduced to the instrument, air was allowed to run through the tubing and instrument until all the rinse solution had drained into the waste container.

Blank: $2 \% \mathrm{HNO}_{3}$

Standard: $100 \mathrm{ppb}$ solution of natural abundance La, Ce, Pr, Nd, Sm, and $\mathrm{Eu}$ in $2 \% \mathrm{HNO}_{3}$.

4) Resuits

a) Uncorrected Results

The counts obtained for the blank were subtracted from the counts obtained for the rare earth sample. Then the net counts for each isotope was ratioed to that of $\mathrm{m} / \mathrm{z}=145$. See figure 3 for the uncorrected ratios and figure 4 for net sample counts.

b) Corrected Results

The data was corrected for the instrumental mass bias that was determined using the natural abundant rare earth $100 \mathrm{ppb}$ standard. 
Mass Bias Determination - (See figure 5 for calculations) The courits obtained for the blank were subtracted from the counts obtained for the standard. Then the counts from the standard were normalized based on the percent abundance at each mass. The normalized counts were then fit to a second order polynomial where $x=m / z$ and $y=$ normalized counts. Using that equation, new normalized counts were extracted for each $\mathrm{m} / \mathrm{z}$ and then ratioed to that of $m / z=145$. The resulting ratios represent the mass bias at each $\mathrm{m} / \mathrm{z}$ relative to $\mathrm{m} / \mathrm{z}=145$. There is a $12 \%$ mass bias over the mass range of 136 to 154 . The mass bias for 155 and 156 , relative to 145 , is assumed to equal 1.02 .

Mass Bias Data Correction - (See figure 4 for calculations) The counts obtained for the blank were subtracted from the counts obtained for the rare earth sample. The net counts were then corrected for the mass bias by dividing the counts at each $\mathrm{m} / \mathrm{z}$ by the mass bias determined for that $\mathrm{m} / \mathrm{z}$. These corrected counts were than ratioed to that of $\mathrm{m} / \mathrm{z}=145$. The statistics for the corrected ratios are shown in figure 6 .

Figure 7 lists the final uncorrected and corrected ratios and their corresponding error. The corrected ratios should be more accurate. 


\begin{tabular}{|c|c|c|c|c|c|c|c|c|c|c|c|c|c|c|c|}
\hline $\mathrm{m} / \mathrm{z}$ & 136 & 137 & 138 & 139 & 140 & 141 & 112 & 14.3 & 144 & 145 & 146 & 117 & 148 & 149 & 150 \\
\hline run $\| 1$ & 75 & 50 & 197 & 40 & 38 & 36 & 33 & 28 & 30 & 28 & 29 & 20 & 31 & 29 & 30 \\
\hline run $\# 2$ & 35 & 32 & 59 & 32 & 29 & 32 & 31 & 29 & 28 & 31 & 28 & 32 & 32 & 34 & 31 \\
\hline run $\| 3$ & 36 & 33 & 56 & 31 & 31 & 33 & 29 & 32 & 30 & 32 & 28 & 29 & 29 & 29 & 31 \\
\hline $\operatorname{run~} 14$ & 35 & 27 & 53 & 32 & 29 & 29 & 29 & 29 & 29 & 30 & 32 & 32 & 34 & 30 & 30 \\
\hline $\operatorname{run} \# 5$ & 63 & 47 & 162 & 30 & 30 & 30 & 30 & 31 & 31 & 30 & 33 & 30 & 29 & 39 & 29 \\
\hline Iun 16 & 60 & 48 & 146 & 34 & 41 & 32 & 30 & 32 & 26 & 28 & 26 & 33 & 29 & 30 & 32 \\
\hline IIIn 117 & 57 & 47 & 133 & 37 & 34 & 32 & 31 & 30 & 30 & 33. & 29 & 32 & 30 & 33 & 34 \\
\hline & & & & & & & & & & & & & & & \\
\hline $\mathrm{m} / \mathrm{z}$ & 151 & 152 & 153 & 154 & 155 & 156 & 157 & 158 & 159 & 160 & 161 & 162 & 163 & 164 & 166 \\
\hline Iun III & 36 & 29 & 33 & 30 & 28 & 24 & 30 & 29 & 30 & 25 & 28 & 29 & 27 & 29 & 27 \\
\hline IIII \#2 & 31 & 28 & 29 & 30 & 29 & 27 & 29 & 30 & 30 & 28 & 29 & 28 & 29 & 28 & 28 \\
\hline Iun $\# 3$ & 27 & 29 & 32 & 31 & 31 & 34 & 31 & 2 & 30 & 34 & 30 & 32 & 30 & 32 & 29 \\
\hline IIIn $\# 4$ & 30 & 31 & 28 & 32 & 35 & 31 & 29 & 32 & 27 & 31 & 27 & 29 & 32 & 30 & 27 \\
\hline Iun 115 & 28 & 32 & 31 & 28 & 31 & 29 & 32 & 27 & 31 & 31 & 30 & 26 & 20 & 29 & 30 \\
\hline Iun 116 & 30 & 28 & 31 & 30 & 30 & 32 & 29 & 31 & 30 & 29 & 31 & 29 & 33 & 30 & 30 \\
\hline Iun $H 7$ & 34 & 30 & 28 & 30 & 29 & 31 & 28 & 31 & 27 & 33 & 29 & 29 & 31 & 29 & 29 \\
\hline
\end{tabular}


Figure 2: Data for Natural Abundant Standard (cps)

\begin{tabular}{|c|c|c|c|c|c|c|c|}
\hline & & & & 1 & $!$ & 1 & \\
\hline $\mathrm{m} / \mathrm{z}$ & 136 & $138 !$ & 139 & 1401 & 1411 & 1431 & 145 \\
\hline run $\# 1$ & 4691 & 8041 & 231435 & 2194531 & 2642181 & 322261 & 22479 \\
\hline run $\# 2$ & 4611 & 8181 & 234337 & 222374 & 2671811 & 324401 & 22523 \\
\hline run $\# 3$ & 484 & 8241 & 242518 & 2294591 & 274939 & 33264 & 23156 \\
\hline run $\nRightarrow 4$ & 5021 & 919 & 249812 & 2369791 & 284679 & 345701 & 24044 \\
\hline run $\# 5$ & $508 !$ & $932 !$ & 2496761 & 2360141 & $284535 i$ & 346971 & 24000 \\
\hline run \#6 & 508 & $962 !$ & 2513521 & 2385551 & 2880361 & 351391 & 24471 \\
\hline average & 489 & 877 & 243188 & 2305721 & 2772651 & 337231 & 23446 \\
\hline \multirow[t]{3}{*}{ std. dev } & 20.491 & 68.751 & 8597.031 & 8165.311 & $10011.50 \mathrm{i}$ & 1246.511 & 846.91 \\
\hline & & & 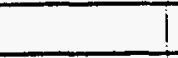 & & & 1 & \\
\hline & & & & & & 1 & \\
\hline $\mathrm{m} / \mathrm{z}$ & 1461 & 147 & 149 & 151 & 1521 & 1531 & 154 \\
\hline run \#1 & 469581 & 39185 & 36888 & 131559 & 730901 & $146802 !$ & 63097 \\
\hline run $\# 2$ & 46956 & 39388 & 369231 & 132273 & 73121 & 147049 & 63016 \\
\hline run $\# 3$ & 483311 & 40600 & 37981 & 135427 & 748961 & 150717 & 64777 \\
\hline run $\# 4$ & 504511 & 422801 & 39632 & 140559 & 780171 & 156434 & 67088 \\
\hline run $\# 5$ & 50437 & 423991 & 39558 & 140972 & 779341 & 1563431 & 67063 \\
\hline run $\# 6$ & $51052 !$ & 427281 & 40068 & 142909 & 79012 & 158630 & 68071 \\
\hline average & 490311 & 41097 & 38508 & 1372831 & 760121 & 1526631 & 65519 \\
\hline sid. dev & 05211 & 606091 & 42025 & 4843.59 & 2640.29 & 5157.971 & 2192.72 \\
\hline
\end{tabular}

D. 8 


\begin{tabular}{|c|c|c|c|c|c|c|c|c|}
\hline ralio & $136 / 145$ & $137 / 145$ & $138 / 145$ & $139 / 145$ & $140 / 115$ & $141 / 145$ & $142 / 145$ & $143 / 145$ \\
\hline IIIn $甘 1$ & 0.00565 & 0.00758 & 0.04987 & 1.68914 & 1.92111 & 1.65624 & 1.67428 & 1.20697 \\
\hline !II $\mathrm{H} 2$ & 0.00492 & 0.00671 & 0.04357 & 1.48644 & 1.76736 & $1.5748 \theta$ & 1.56516 & 1.18703 \\
\hline $\operatorname{lin} 13$ & 0.00474 & 0.00675 & 0.04453 & 1.49578 & 1.77055 & 1.57617 & 1.56759 & 1.18713 \\
\hline IIII 14 & 0.00483 & 0.00665 & 0.04437 & 1.50142 & 1.77584 & 1.57833 & 1.56117 & 1.19022 \\
\hline Iun 15 & 0.00576 & 0.00801 & 0.05160 & 1.69994 & 1.94227 & 1.67432 & 1.68623 & 1.21045 \\
\hline run 46 & 0.00581 & 0.00796 & 0.05149 & 1.69695 & 1.92972 & 1.66292 & 1.68261 & 1.20432 \\
\hline ! IU! $\# 7$ & 0.00576 & 0.00798 & 0.05132 & 1.70964 & 1.94692 & 1.67520 & 1.68893 & 1.21178 \\
\hline average & 0.00535 & 0.00738 & 0.04811 & 1.61133 & 1.86482 & 1.62829 & 1.63228 & 1.19970 \\
\hline sid. dev. & 0.00049 & 0.00065 & 0.00375 & 0.10949 & 0.08796 & 0.04893 & 0.06346 & 0.01113 \\
\hline ralio & $144 / 145$ & $146 / 145$ & $147 / 145$ & $148 / 145$ & $149 / 145$ & $150 / 145$ & $151 / 145$ & $152 / 145$ \\
\hline run $\| 1$ & 1.87479 & 0.97141 & 0.42571 & 0.70470 & 0.00380 & 0.62029 & 0.01619 & 0.15968 \\
\hline Iun H2 & 1.85909 & 0.98256 & 0.44357 & 0.73017 & 0.00418 & 0.66040 & 0.01737 & 0.17431 \\
\hline IIII $\mathrm{H3}$ & 1.85601 & 0.97679 & 0.44243 & 0.72584 & 0.00391 & 0.65253 & 0.01730 & 0.17347 \\
\hline IIII $\# 4$ & 1.86218 & 0.97731 & 0.44210 & 0.72796 & 0.00416 & 0.66082 & 0.01783 & 0.17409 \\
\hline IIIn $\forall 5$ & 1.88168 & 0.97789 & 0.42916 & 0.70818 & 0.00386 & 0.62787 & 0.01650 & 0.16180 \\
\hline run 16 & 1.87453 & 0.97127 & 0.42539 & 0.70609 & 0.00384 & 0.62412 & 0.01657 & 0.16189 \\
\hline IIII 117 & 1.87978 & 0.97373 & 0.42874 & 0.70868 & 0.00403 & 0.62531 & 0.01645 & 0.16219 \\
\hline average & 1.86972 & 0.97585 & 0.43387 & 0.71595 & 0.00397 & 0.63876 & 0.01689 & 0.16678 \\
\hline sld. dev. & 0.01042 & 0.00403 & 0.00839 & 0.01141 & 0.00016 & 0.01825 & 0.00061 & 0.00677 \\
\hline ratio & $153 / 145$ & $154 / 145$ & $155 / 145$ & $156 / 145$ & & & & \\
\hline Iun $\mathrm{HI}$ & 0.14569 & 0.07385 & 0.03988 & 0.11768 & & & & \\
\hline Iu H2 & 0.16215 & 0.08258 & 0.03855 & 0.12575 & & & & \\
\hline run $\mathrm{H}$ & 0.16100 & 0.08188 & 0.04065 & 0.12724 & & & & \\
\hline rinn $\# 4$ & 0.16140 & 0.08264 & 0.04026 & 0.12744 & & & & \\
\hline IIIn 15 & 0.14930 & 0.07567 & 0.03158 & 0.11527 & & & & \\
\hline IIIII H6 & 0.14791 & 0.07583 & 0.03246 & 0.11634 & & & & \\
\hline run 17 & 0.14947 & 0.07613 & 0.03452 & 0.11943 & & & & \\
\hline averago & 0.15386 & 0.07837 & 0.03681 & 0.12131 & & & & \\
\hline sid. dev. & 0.00730 & 0.00382 & 0.00389 & 0.0053 .3 & & & & \\
\hline
\end{tabular}




\begin{tabular}{|c|c|c|c|c|c|c|c|c|c|c|c|}
\hline 50951 & म1CIO & GटSE $2 \bar{S}$ & $\bar{s} \bar{E}+\bar{s}$ & $\bar{\theta} \bar{z} \bar{z} \overline{0}$ & $60 \overline{9} \div \overline{2}+9 i$ & $\bar{\varepsilon} \angle \overline{G I}$ & LESIIO & SECLCOFIC & CSISE & 201 & {$[\overline{9} \overline{s !}$} \\
\hline 1198 & $5 \bar{\theta} 60$ & ELCIE & $1 E 6$ & $6 \angle 2 E 0$ & QCIEV & E20 & $0 i \overline{E 0} 0$ & จัテ & EIBI & 201 & $\overline{\underline{s}} \underline{\underline{s}} \mathbf{i}$ \\
\hline $0<15$ & $8 \overline{2} 0800$ & $\overline{C S}+\bar{B} \bar{\theta} \bar{C} \angle \bar{G}$ & $\bar{E} \overline{6} \overline{6}$ & $\angle 60800$ & 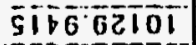 & ZECOI & $1 B \overline{2} \angle 0$ & $62956291 \overline{2}$ & $190 \bar{c}$ & 566101 & is $\mathbf{i}$ \\
\hline 90981 & $59 \angle S T^{\circ}$ & 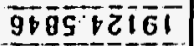 & IESGi & $\bar{B} \angle \bar{B} \bar{O}$ & टC58 & $\angle \overline{B C} \bar{C}$ & $99 \overline{2}$ & EQESTOLD & İs & 921201 & Es $\bar{i}$ \\
\hline 15661 & 626910 & $6 \angle 959690 \overline{2}$ & $E 5012$ & $190 i 10$ & 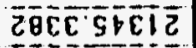 & 80812 & 629510 & $9850<0996$ & 66926 & $89 i \overline{20}$ & $\overline{2} \bar{s} i$ \\
\hline EDOZ & 169100 & $2998 \mathrm{~s} 50 \overline{2}$ & $660 \overline{2}$ & $10 \angle 100$ & FOG & $E \leq 12$ & SQS100 & $\angle L 91 \mathrm{~s}$ c $\angle \bar{E}$ & $\overline{9} \varepsilon \overline{8}$ & $\bar{z} \bar{i} i \bar{c} \bar{i}$ & Isi \\
\hline$\overline{O C L S L}$ & 186890 & $169219 L L$ & $9916 L$ & $\bar{L} \bar{L}+9^{\circ}$ & 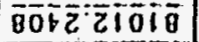 & cटgZ8 & $0=8090$ & $812 \angle 29101$ & $\overline{0} \overline{\overline{2}} \overline{\mathrm{s}} \overline{01}$ & 906101 & $\overline{0} \overline{s i}$ \\
\hline 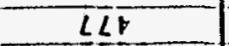 & 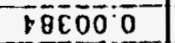 & 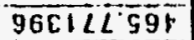 & $F<5$ & 115000 & $92026 \mathrm{CIS}$ & $\overline{\mathrm{C}} \overline{\mathrm{g}}$ & $\varepsilon \angle C 00^{\circ} 0$ & 67962511 & $\mathrm{~s} \overline{c ! 1}$ & $\angle 96101$ & 6 \\
\hline$\triangle 2068$ & $1+9110$ & ir ç一大 & $6508 \overline{8}$ & $\overline{89} \overline{\angle L} 0$ & $6 \overline{66005006}$ & 29टí & 856690 & 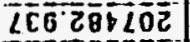 & $9090 \bar{z}$ & $\angle \overline{5} 5101$ & $\overline{8} i$ \\
\hline 99909 & $6 L L E E 0$ & giólOOES & $0 \angle \overline{9 C S}$ & $26 \theta \overline{0} 0$ & 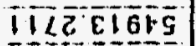 & 56̄5 & 治位。 & 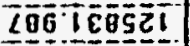 & s9ilci & 650101 & ini \\
\hline 000211 & İं $\angle \sigma^{\circ} 0$ & $11910<11$ & 165811 & $569 \angle 60$ & $\bar{s} \bar{\sigma} \bar{L} \bar{z} \bar{c} \bar{c} \bar{l}$ & $62 \overline{221}$ & $\angle 85960$ & $7 \overline{6} \overline{0} \overline{0} \overline{5} \overline{8} \bar{c}$ & 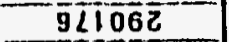 & 15001 & $30 i$ \\
\hline $009+11$ & 000001 & $=\angle O E I Z I$ & LoE & 000001 & १i़ि! & TISटI & 000001 & 912062 & $9 ! \leq 86 \overline{2}$ & 000001 & $\bar{s} \bar{i}$ \\
\hline $90 \bar{c} i \bar{z}$ & $\angle \bar{c} \overline{3} \bar{\theta}$ & FटL919gटz & 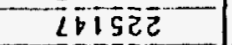 & 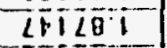 & 9IE & $\bar{z} \bar{s} \bar{z} \bar{c} \bar{z}$ & $8 \overline{2} 2 \overline{8} 1$ & $91619<695$ & icoogs & बिद्ध $6 \overline{0}$ & $\mid \bar{B} i$ \\
\hline $66 \overline{6} \mathrm{cI}$ & $2180 \bar{i}$ & टह9 в9095i & 100011 & EOBOZ। & ilicgosi & IIs & $\bar{c}+\bar{c} \mathrm{l}$ & 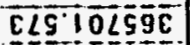 & $0+509 \bar{c}$ & $\overline{6} \overline{9} \overline{8} \overline{0}$ & $\bar{c} \bar{i}$ \\
\hline $0168 \leq 1$ & $99<091$ & $98 \mathrm{E} S \mathrm{SS} 61$ & $09 i 06 i$ & (1109! & $\overline{\mathrm{C}} \overline{\mathrm{S}} \overline{\mathrm{V}} \overline{\mathrm{C}} \overline{\mathrm{C}} \overline{\mathrm{O}} \overline{\mathrm{Z}}$ & 618561 & 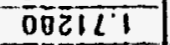 & 999if9its & TE1009 & $19 i \leq \overline{6}$ & $2 i i$ \\
\hline$\angle \angle 008 i$ & $98<\overline{8} \cdot 1$ & TLEOLELGI & IOŻiG & 25929 & $\overline{0} \overline{2} \overline{6} 6 \mathrm{CO} \bar{z}$ & $5 \bar{c} 0<\overline{6}$ & 550121 & C9990015 & $7 6 \longdiv { 6 6 0 }$ & s 28960 & iti \\
\hline IISEOZ & $56 i+\theta$ & $18969172 \bar{z}$ & $0 B L \square$ & 295801 & $9 \angle 9 \div 8<0 \mathrm{C}$ & 9i门己 & 015002 & LIISSGQ69 & $\angle 98 \overline{8} 5$ & 118960 & óti \\
\hline $\operatorname{cg} 0 \overline{2} \leq 1$ & $E E 6<5$ & $629 \mathrm{Egs} 661$ & B5-181 & $\angle 66951$ & 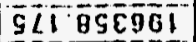 & $0<6501$ & $0 \bar{E} \bar{B} \mathrm{~L}$ & $\angle 0 \overline{6} \overline{\mathrm{S}} L \overline{\mathrm{C}} \mathrm{s}$ & TLSBOS & $0 i<60$ & $\overline{6} \bar{c} i$ \\
\hline 9805 & $29 \angle b 00$ & $1 B \angle 1 C 9 \angle \angle s$ & $\overline{2} \overline{0} \bar{s}$ & $659=0$ & 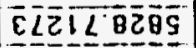 & $19 \overline{9}$ & 乙大E $\overline{500}$ & $\overline{2} 621$ B 269 & 96851 & $0 \overline{5 E 6} 0$ & $\bar{\theta} \bar{E}$ \\
\hline 291 & $2 E \angle 000$ & $6 \overline{9} 61 \overline{8} \div \overline{0}$ & 610 & $\angle 2 \angle O 00$ & 690595606 & $6 C 8$ & टरे०00 & $\overline{s L} 6 \overline{s g} \overline{2}$ & $592 \overline{2}$ & $\bar{z} \bar{z} \theta 0$ & LEi \\
\hline 155 & ट己 5000 & $\angle 606 \overline{2} \overline{2} \bar{c}$ & $\bar{S} \bar{S}$ & 215000 & $\bar{C} \bar{S} \bar{B} \quad Z \bar{Q}$ & 919 & 129000 & siz $\angle \bar{c} \bar{s} \bar{\theta} i$ & $\angle 891$ & $9 \angle \bar{B} 0 \overline{0}$ & $9 \overline{c i}$ \\
\hline Iก บii & & cuuns & Cर & & Enบบiii & 21 & & Iกับ & II Uni & $\bar{s} \mid=i j u$ & i iui \\
\hline Tsdô sfunos & Sक्र वा o!ाes & (sdj) siutios & (sdo) słunos & 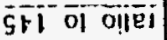 & $\mid$ sdj $\rangle^{-}$s|unios & (sj5) sluiros & 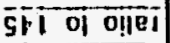 & 7 sdo $\longdiv { \text { siuilos } }$ & $7 \bar{s} 0 \overline{\text { spunos }}$ & of on!p|ai & \\
\hline popesquis xuela & & po1301100 & 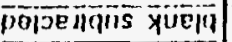 & & poijoilos & 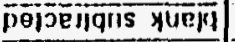 & & pojōijos & 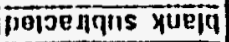 & seja sseu & \\
\hline & & & & & & & & & & & \\
\hline & & & & & & & & & & & \\
\hline
\end{tabular}




\begin{tabular}{|c|c|c|c|c|c|c|c|c|c|c|c|}
\hline \multirow{4}{*}{ conisclod } & & & & & & & & & & & \\
\hline & & & & & \multirow[b]{2}{*}{ blank sublraclod } & & & \multirow[b]{2}{*}{ Wlank subliaclod } & \multirow[b]{2}{*}{ corrocled } & & \\
\hline & eatlo lo 45 & tuank subiracled & carlecled & & & colreclod & & & & \multirow{3}{*}{ ialio $10 \quad 145$} & \\
\hline & tallo lo ?15 & counts (cPs) & counts (cPs) & Iallo lo 145 & coun!s_(cps) & counts_(cps) & alio to 145 & counls (cps) & counts JCESL. & & \\
\hline IIIn!4 & & $\operatorname{lng} 15$ & $\ln 15$ & & III!) 16 & IIIn 16 & & IIIn 17 & IIIIn] & & $\overline{0 n / 2}$ \\
\hline 609.62073 & 0.00532 & 765 & B41.804799 & 0.00634 & 732 & 005.491651 & 0.00640 & 695 & 764.776909 & 0.00633 & 136 \\
\hline B26.087906 & 0.00721 & 1063 & 1152.40350 & 0.00068 & 1002 & 1006.27318 & 0.00863 & 964 & 104507719 & 0.00865 & 137 \\
\hline 5137.35172 & 0.01745 & 6851 & 7325.72206 & 0.05517 & 6484 & 6933.29176 & 0.05506 & 6197 & 6626.40484 & 0.05487 & 138 \\
\hline 161671.338 & 158529 & 225725 & 238333.666 & 1.79490 & 213682 & 225618.151 & 1.79171 & 206154 & 217966.399 & 1.80514 & 139 \\
\hline 212108026 & 1.05317 & 257902 & 269176.871 & 2.02718 & 242992 & 253615043 & 2.01408 & 235100 & 245386.373 & 2.03203 & $14 \overline{0}$ \\
\hline 106807.940 & 1.63009 & 222323 & 229612.96 & 1.72922 & 209396 & 216262004 & 1.7174. & 202295 & 208928.243 & 1.73013 & 111 \\
\hline 103026.535 & 1.59709 & 223905 & 229056.023 & 1.72503 & 211876 & 216751.040 & $1.72 \div 33$ & 203954 & 200646.77 & 1.72779 & 142 \\
\hline 196351.210 & 1.20726 & 160728 & 163029019 & 1.22778 & 151649 & 153020.042 & 1.22156 & 146333 & 148427.937 & 1.22913 & $14 \overline{3}$ \\
\hline $2 ! 182 ! .5 ! 6$ & 1.87159 & 249857 & 251521.310 & 1.89421 & 236043 & 237615.303 & 188702 & 227000 & 228512.067 & 1.89230 & 144 \\
\hline 111600 & 1.00000 & 132784 & 132784 & 1.00000 & 125921 & 125921 & 1.00000 & 120759 & 120759 & 1.00000 & 145 \\
\hline $1 ! ! 36 ! .136$ & 0.97171 & 129040 & 129107.320 & 0.97231 & 122303 & 121605366 & 0.96573 & 117587 & 116916.267 & 0.96818 & 116 \\
\hline 50133.9018 & 0.43747 & 56986 & 563086416 & 0.12466 & 53565 & 53003.5024 & 0.42093 & 51774 & 512312767 & 0.42424 & $17 \overline{7}$ \\
\hline 02225.9534 & 0.11750 & 04035 & 92681.5695 & 0.69001 & 00912 & 87635.1106 & 0.69595 & 85500 & 04350.9912 & 0.69851 & $1+8$ \\
\hline 160.719316 & 0.00409 & 513 & 504091359 & 0.00380 & 404 & 475.597797 & 0.00378 & 487 & 478.545717 & 0.00396 & 149 \\
\hline 71253.6210 & 0.64784 & 83371 & 61715.6503 & 0.61563 & 78590 & 770570653 & 0.61195 & 75512 & 740390710 & 0.61312 & 150 \\
\hline 20005502 & 0.01716 & 2191 & 2145.47503 & 0.01616 & 2087 & 204363596 & 0.01623 & 1987 & 194571377 & 0.01611 & $15 \overline{1}$ \\
\hline 10527.7319 & 0.17010 & 21485 & 21029.1907 & 0.15日37 & 20385 & 19952.5275 & 0.15845 & 19586 & 191701785 & 0.15875 & 152 \\
\hline 10120.0135 & 0.15812 & 19825 & 194124668 & 0.14620 & 18625 & 182374373 & 0.14483 & 10050 & 17674.4023 & 0.14636 & 153 \\
\hline 9294.79922 & 0.00102 & 10048 & 9051.49552 & 0.07119 & 9540 & 9361.27381 & 0.07434 & 9193 & 9013.2164 & 0.07464 & 154 \\
\hline 4523.52941 & 0.03917 & 4193 & 4110.70131 & 0.03096 & 4087 & 400606275 & 0.03182 & 4169 & 40872549 & 003385 & 155 \\
\hline 14310.6275 & 0.12404 & 15306 & 150050121 & 0.11301 & 11650 & 14362.74 & 011406 & 14422 & 141392157 & 0.11709 & $1 \overline{5} \overline{6}$ \\
\hline
\end{tabular}




\begin{tabular}{|c|c|c|c|c|c|}
\hline & & & & $x=$ mass & \\
\hline & & & & normalized counus & mass bias \\
\hline & nalural abundance & counls Irom nat & normalized & as extracled lrom & relative 10 \\
\hline mass & a! thal mass (\%) & abund. sld. (cps) & counls (cps) & 2nd oder lii & $\mathrm{m} / \mathrm{z}=145$ \\
\hline 136 & 0.19 & 489 & 257368.1211 & 256348.928 & 0.90876 \\
\hline 137 & & & & 260201.702 & 0.92242 \\
\hline 138 & $0.09+0.26=0.35$ & 876 & 250205.7143 & 2638062 & 0.93520 \\
\hline 139 & 99.9 & 243180 & 243431.4314 & 267162.122 & 0.94710 \\
\hline 140 & 80.5 & 230572 & 260533.3333 & 270270.368 & 0.95811 \\
\hline 141 & 100 & 277265 & 277265 & 273130.038 & 0.96825 \\
\hline 142 & $11.1+27.1=38.2$ & 104397 & 273290.5759 & 275741.432 & 0.97751 \\
\hline 143 & 12.2 & 33723 & 276418.0328 & 278104.55 & 0.98589 \\
\hline 144 & $23.9+3.1=27.0$ & 74939 & 277551.8519 & 280219.392 & 0.99338 \\
\hline 145 & 8.3 & 23445 & 2824698795 & 202085.358 & 1.00000 \\
\hline 146 & 17.2 & 49031 & 285063.9535 & 283704248 & 1.00571 \\
\hline 147 & 15 & 41097 & 273900 & 285074262 & 1.01059 \\
\hline 148 & $5.7+11.2=16.9$ & 47969 & 283840.2367 & 286196 & 1.01157 \\
\hline 149 & 13.8 & 38508 & 279043.4783 & 207069.462 & 1.01767 \\
\hline 150 & $5.6+7.4=13.0$ & 37498 & 288446.1538 & 287694648 & 1.01988 \\
\hline 151 & 47.8 & 137283 & 287202.9289 & 288071.558 & 1.02122 \\
\hline 152 & 26.7 & 76012 & 284689.1386 & 288200.192 & 1.02168 \\
\hline 153 & 52.2 & 152662 & 2924559387 & 280000.55 & 1.02125 \\
\hline 154 & 22.8 & 65519 & 287364.0351 & 287712.632 & 1.01995 \\
\hline 155 & & & & & 1.02000 \\
\hline 156 & & & & & 1.02000 \\
\hline 157 & & & & & \\
\hline 158 & & & & & \\
\hline 159 & \multicolumn{4}{|c|}{ he normalized counls were fil to a 2 nd order polynomial } & \\
\hline 160 & \multirow{2}{*}{\multicolumn{4}{|c|}{$y=-26565.19+38239 \times 124.138 \times 2 \quad B=0.8 B 3$}} & \\
\hline 161 & & & & & \\
\hline
\end{tabular}


Fignure 6: Slatislics for Currected flatios

\begin{tabular}{|c|c|c|c|c|c|c|c|c|}
\hline ralio & $136 / 145$ & $137 / 145$ & $130 / 115$ & $139 / 115$ & $140 / 115$ & $141 / 145$ & $142 / 145$ & $143 / 145$ \\
\hline IIIIN $\# 1$ & 0.00621 & 0.00022 & 0.05332 & 1.78350 & 2.00510 & 1.71054 & 1.71280 & 1.22425 \\
\hline IIIII $\mathrm{H2}$ & 0.00542 & 0.00727 & 0.04659 & 1.56947 & 1.84462 & 1.62652 & 1.60117 & 1.20403 \\
\hline IIII 113 & 0.00522 & 0.00732 & 0.04762 & 1.57933 & 1.84795 & 1.62786 & 1.60366 & 1.20412 \\
\hline IIIII $\mathrm{HA}$ & 0.00532 & 0.00721 & 0.04745 & 1.58529 & 1.85347 & 1.63009 & 1.59709 & 1.20726 \\
\hline Iun 15 & 0.00634 & 0.00868 & 0.05517 & 1.79490 & 2.02718 & 1.72922 & 1.72503 & 1.22778 \\
\hline ruIn $\| 6$ & 0.00640 & 0.00863 & 0.05506 & 1.79174 & 2.01408 & 1.71744 & 1.72133 & 1.22156 \\
\hline IIII 17 & 0.00633 & 0.00865 & 0.05487 & 1.80514 & 2.03203 & 1.73013 & 1.72779 & 1.22913 \\
\hline average & 0.00589 & 0.00800 & 0.05141 & 1.70134 & 1.94635 & 1.68169 & 1.66984 & 1.21687 \\
\hline sid. dev. & 0.00054 & 0.00070 & 0.00401 & 0.11561 & 0.09181 & 0.05053 & 0.06492 & 0.01129 \\
\hline ratio & $144 / 145$ & $146 / 145$ & $147 / 145$ & $148 / 145$ & $149 / 145$ & $150 / 145$ & $151 / 145$ & $152 / 145$ \\
\hline IIIn II! & 1.88728 & 0.96587 & 0.42124 & 0.69458 & 0.00373 & 0.60820 & 0.01585 & 0.15629 \\
\hline IIII 112 & 1.87147 & 0.97695 & 0.43892 & 0.71968 & 0.00411 & 0.64752 & 0.01701 & 0.17061 \\
\hline $\operatorname{mon} \mathrm{H3}$ & 1.86837 & 0.97121 & 0.43779 & 0.71541 & 0.00384 & 0.63981 & 0.01694 & 0.16979 \\
\hline IIIII $\| 4$ & 1.07459 & 0.97174 & 0.43747 & 0.71750 & 0.00409 & 0.64794 & 0.01746 & 0.17040 \\
\hline IIII 115 & 1.09121 & 0.97231 & 0.42466 & 0.69801 & 0.00380 & 0.61563 & 0.01616 & 0.15837 \\
\hline $\min \| 6$ & 1.88702 & 0.96573 & 0.42093 & 0.69595 & 0.00378 & 0.61195 & 0.01623 & 0.15845 \\
\hline $\operatorname{lin} 117$ & 1.89230 & 0.96818 & 0.42424 & 0.69851 & 0.00396 & 0.61312 & 0.01611 & 0.15875 \\
\hline average & 1.88218 & 0.97028 & 0.42932 & 0.70566 & 0.00390 & 0.62631 & 0.01654 & 0.16324 \\
\hline sid. dev. & 0.01049 & 0.00401 & 0.00830 & 0.01124 & 0.00015 & 0.01790 & 0.00059 & 0.00663 \\
\hline Ialio & $153 / 115$ & $154 / 1 / 5$ & $155 / 145$ & $156 / 145$ & & & & \\
\hline $\operatorname{minn} \| 1$ & 0.14266 & 0.07241 & 0.03910 & 0.11537 & & & & \\
\hline iIIn 112 & 0.15878 & 0.08097 & 0.03779 & 0.12329 & & & & \\
\hline $\operatorname{mnn} \| 3$ & 0.15765 & 0.08028 & 0.03985 & 0.12474 & & & & \\
\hline IIIn 14 & 0.15812 & 0.08102 & 0.03947 & 0.12494 & & & & \\
\hline (IIII 115 & 0.14620 & 0.07419 & 0.03006 & 0.11301 & & & & \\
\hline $\operatorname{mon} 116$ & 0.14483 & 0.07434 & 0.03182 & 0.11406 & & & & \\
\hline IIIn 117 & 0.14636 & 0.07164 & 0.03385 & 0.11709 & & & & \\
\hline average & 0.15066 & 0.07604 & 0.03612 & 0.11893 & & & & \\
\hline sld. dev. & 0.00715 & 0.00374 & 0.00381 & 0.00522 & & & & \\
\hline
\end{tabular}


Figure 7: Final Results

\begin{tabular}{|c|c|c|c|c|}
\hline & 1 & & I & \\
\hline & 1 & & 1 & \\
\hline & 1 & uncorrected & 1 & corrected \\
\hline & $!$ & iatio 10 & & ratio to \\
\hline isotope & $!$ & $m / z=145$ & 1 & $m / z=145$ \\
\hline 136 & & $0.0054=0.0005$ & & $0.0050=0.0005$ \\
\hline 137 & & $0.0074=0.0000$ & 1 & $0.0080=0.0007$ \\
\hline$i 38$ & 1 & $0.048=0.004$ & 1 & $0.05 i=0.004$ \\
\hline 139 & 1 & $1.6=0.1$ & $!$ & $1.7=0.1$ \\
\hline 140 & 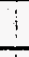 & $i .30=0.09$ & 1 & $1.95=0.09$ \\
\hline 141 & 1 & $1.63=0.05$ & 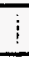 & $1.68=0.05$ \\
\hline$i \leqslant 2$ & $\vdots$ & $1.63=0.06$ & 1 & $1.67=0.06$ \\
\hline 143 & $i$ & $1.20=0.01$ & 1 & $i .22=0.01$ \\
\hline$i<4$ & 1 & $1.37=0.01$ & 7 & $1.88=0.01$ \\
\hline 145 & 1 & 1 & 1 & 1 \\
\hline$i \div 6$ & 1 & $0.976=0.004$ & & $0.970=0.004$ \\
\hline$i 47$ & $i$ & $0.434=0.008$ & 1 & $0.429=0.008$ \\
\hline 148 & 1 & $0.72=0.01$ & 1 & $0.70=0.01$ \\
\hline $1 \leqslant 9$ & & $0.0040=0.0002$ & & $0.0039=0.0002$ \\
\hline 150 & & $\therefore 0.64=0.02$ & 1 & $0.63=0.02$ \\
\hline 151 & & $0.0160=0.0000$ & & $0.0165=0.0006$ \\
\hline 152 & 1 & $0.167=0.007$ & 1 & $0.163=0.007$ \\
\hline 153 & 1 & $0.154=0.007$ & & $0.151=0.007$ \\
\hline 154 & 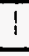 & $0.078=0.004$ & 1 & $0.077=0.004$ \\
\hline 155 & & $0.037=0.004$ & & $0.036=0.004$ \\
\hline .156 & & $0.121=0.005$ & 1 & $0.119=0.005$ \\
\hline 157 & & $0.027=0.002$ & $i$ & \\
\hline $15 \varepsilon$ & & $0.048 \doteq 0.002$ & 1 & \\
\hline $1 \leqq \Xi$ & $!$ & $0.019=0.001$ & 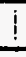 & \\
\hline 160 & 1 & $0.025=0.002$ & $!$ & \\
\hline 151 & $!$ & $0.011=0.001$ & $\bar{T}$ & \\
\hline
\end{tabular}




\section{APPENDIX E}

Khlopin Radium Institute Measurement Data

E.1 


\section{APPENDIX E}

\section{Khlopin Radium Institute Measurement Data}

The Khlopin Radium Institute in St. Petersburg, Russia, employed several measurement approaches to analyze the lanthanide component in spent fuel sample 8781. The lanthanide sample analyzed by the KRI was taken from the larger sample prepared as described in Appendix $A$ and thus was identical to the sample analyzed by PNL and LANL (see Appendices $C$ and D). The measurement techniques used by the KRI were briefly discussed in Appendix B in connection with estimating uncertainties associated with the lanthanide concentrations in the spent fuel samples. More detailed descriptions of the measurements and additional data are presented in the KRI report on the analyses of sample 87-81. The report is reproduced in this appendix. 
Eupean Analytical Serrioes, Ino. (Eepresenting the Tollhopin Radium Institute, stoptiensburs, Russia)

\author{
A.A.Ringhi-Koreakov, A.Y.Stepanov, A.D.Kinilror

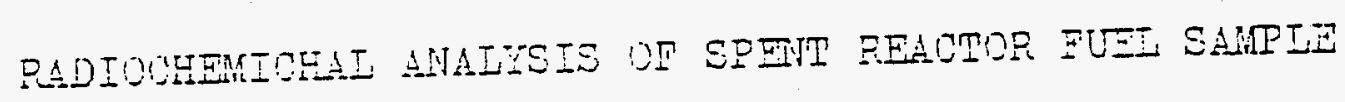 \\ Reporti of Resuits
}

Work performed on : Dontrant on Purohase order No. 190115-4-M2, oi Fobruam 1003 for Eateile Pacific Noptiwest Laboratories, 5 - th a in streets, P.0.50x 909, Rioinland, Washinston 99352 , USA

\author{
St.Petersours
}

1993

E.3 


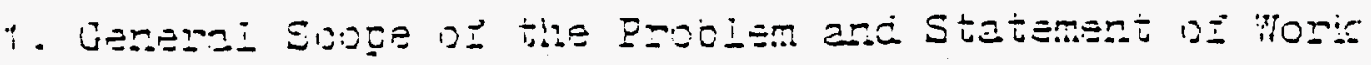

2. Sample Dismiptior.

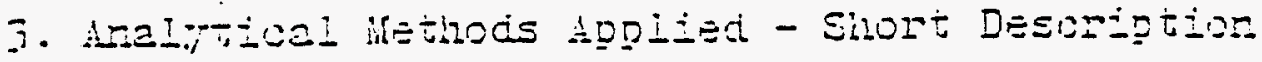

4. Standiands lised in the dralysis

5. Inaitutoa: Jesuita 
1. Gensrai Syove of the Erovlem and Statement of Woris

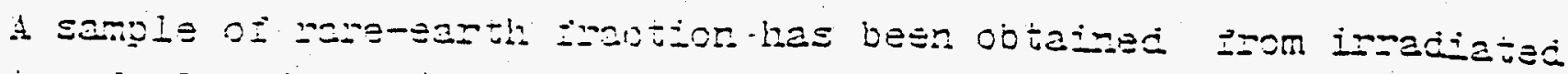
reactor illi and presented ior anaijsis of abundanos ol sererai nuoIires :

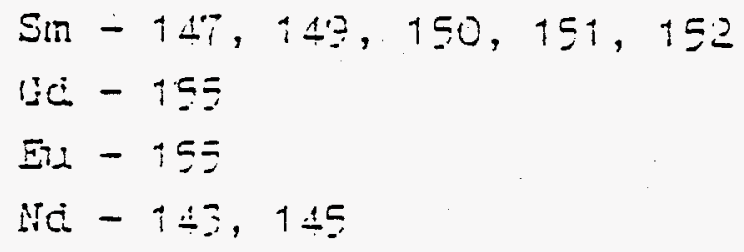

bonentrations mere to be measured eitirer in grams of nuciide per sample of as the amount of rubitie relatite to Ni-i45.

Amons the recuinomente of the Statement oj fork a reviem at

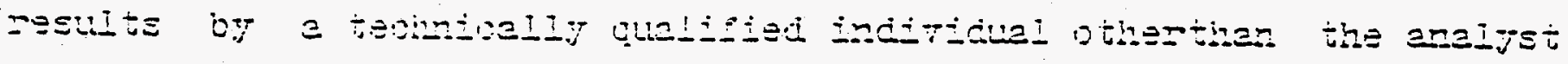
mas stateci.

a. Initiai Samoie Evaiuation and Ereparaiton

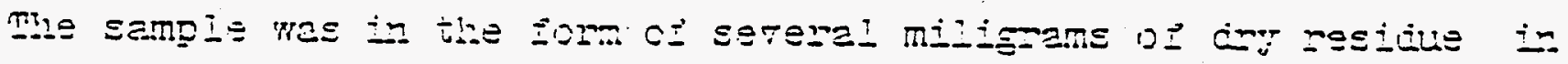

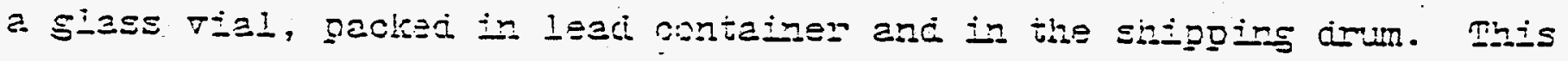
gaviage has bes transportiad by ired IFon lustoms in Maj $190 ;$ - wianaged and sealed.

The EPGi gamm-sgectrometer was used to measure the actirities in

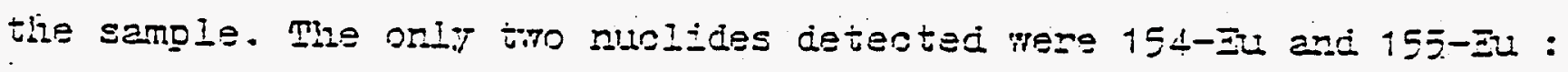

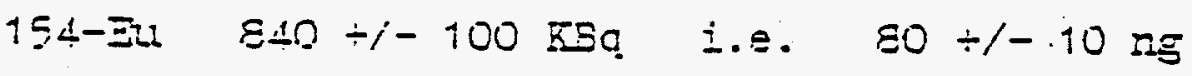

155-zu $230 \div /-30$ Koo i.e. $13+1-2$ ag

Paocedure used complied with the osti 95 10234-36(1.11.498T) Standard - and the sample had not to be removed laom the original vial. mhis measurement was made only to evaluaje the expected anounis oi the Iission products (both racioactive and stable) present in the sampie and $7 i I I$ be sompared later with amounts detested by mass-spectrometry.

Three difierent nethode were chosen for the analysis of the sample: tile secondarg ion mass spectrometry (STMS) por panoramio investigatione of isotopic ratios of rare earthe, Iaser induced Iluorinetry Ior direot determination of total In and Sn content in the sample and conventional isotope dilution mass spectrometsy. . . ih preliminary radiochemical isolation ol pure $\mathrm{Nd}$, Sm, Eu and lä lor greaise determination oI isotode abuaznoes oI tiuse elements ani tuthl ammint:s of 14 and ar. 


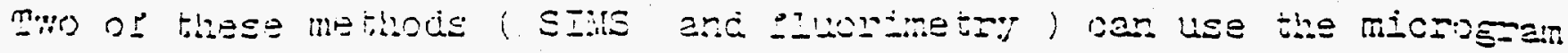

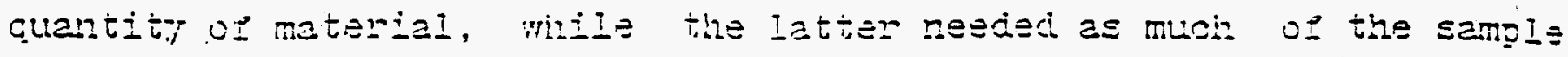

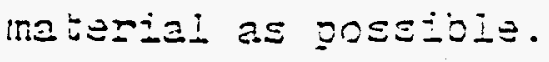

Fon the İIst netiod (SIMS) a sinali (aoout 1/1000) a Iiclot was talisn Irom the sampie. Mhis mas done by touciling the inser waII of the sangle rial with the end oI a giean giatinum wine siigitiy wetted with 0.1 If nitric aoid ard lettins it dry. Repeated gama-spectronetry me-

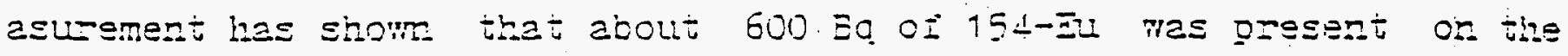

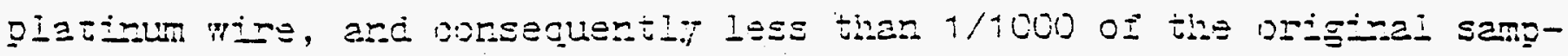
ie mainzial has been Ismores. That giatinum wine was used in the sirss anaijsis as described beiow, anc the rest oi the sampie ment to the

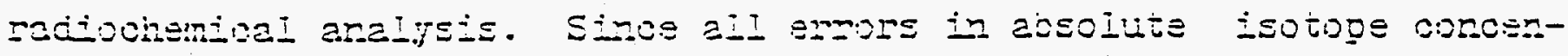
t=ajiors in tine samele weigits are not iess tinan seterai j, we did not

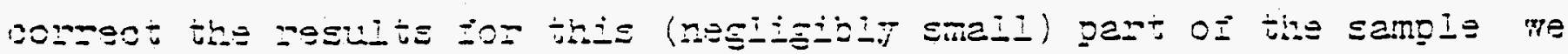
ronovic.

3. AnaIjitoal Metiods Apoized - Sinort Description

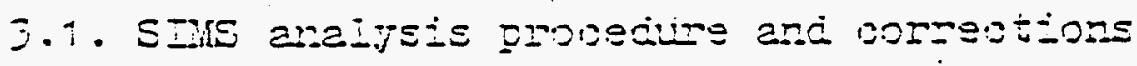

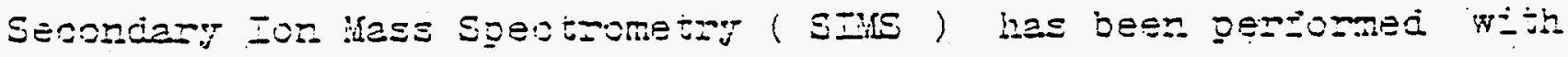

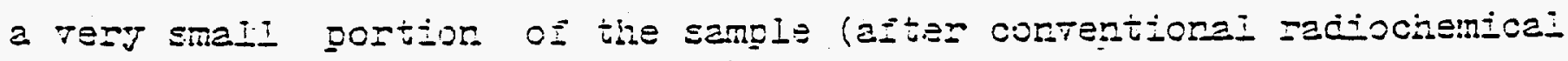
detemination the whole pFe sontant of samole was found to be about 40 miIifgrams and the SISS part oi the samgle ras determined to hate aobut 30 nanogmans, derited as sinom in section 2.). The piatinum wire 耳ith small part oI the original sanpie on it's suriace has best exposed to the 10 as bean oI negative 16-j ions in IUS 4I IOn Microprobe ( DAMEla) mass-spevtrometer. In order to recuce the nolecular ion interierence the enerof-iiltering technigue has been'

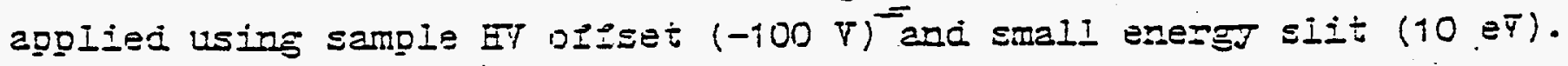
Netertheless the dipierence in the evaporation epioviencJ Iur aifierent elements (Nid, Sm; El and Gi) had to be cormevted for using the standari sample with bmom ponoentrations of the sane elenerts. muis standard had been preparsi Irom natural isotope mirtures of these elenents and certified by the state Institute "Melinanobr" in st.Petersburs (see Section 4, beIow). Cormetion Iactors ( $1 . e$. Iatios oI the element esncentration to one derived from the mass-spestim ) Fruad this mat riese :

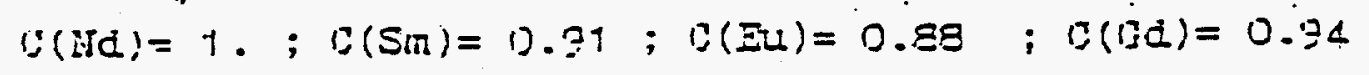




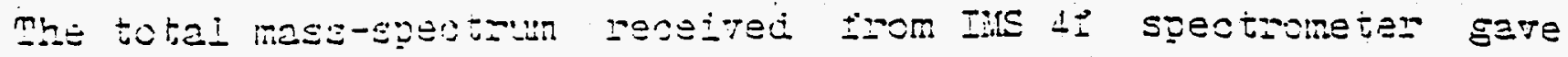

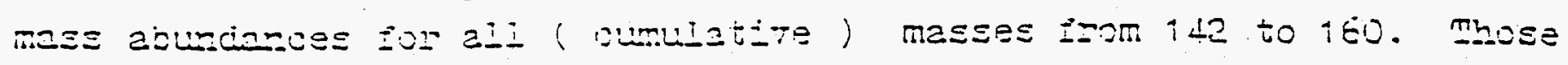
masses that were undouteriy beionsing to sinsie isotope components of dezinite elenests (masses $142-147,149,153,150^{\circ}-160$ ) wero cormected lsins the poezjizients quoted above. minose mass peaks that in alI probabiizif belonged to seteral (mbstit tro ) isotoces

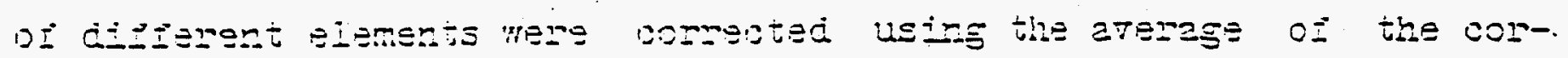

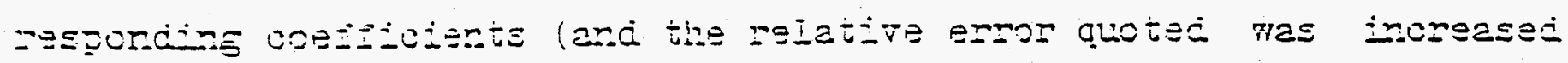

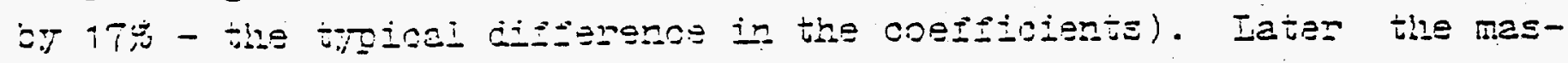
ses For sucin doubiets aro quoted in the resuits as sums oi ail eie-

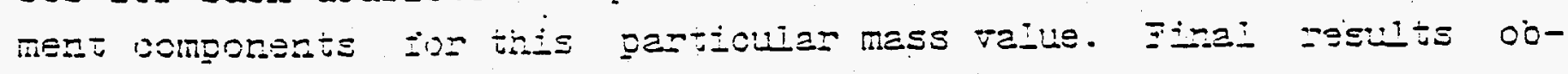

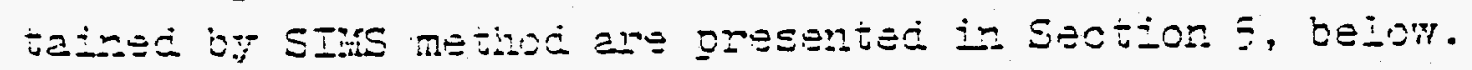

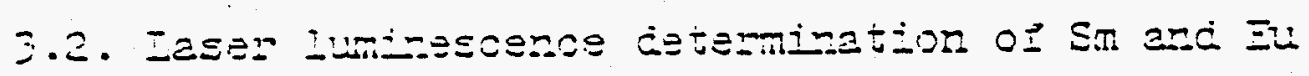

Lbsoiute measunoment oi Sn and Eu anount in the sangie was cone

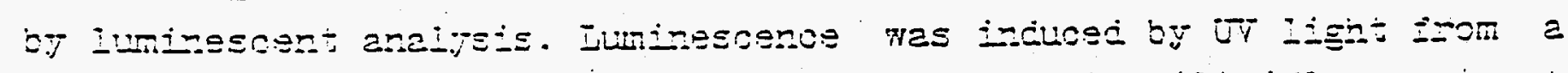

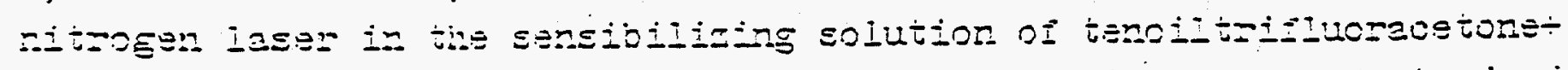

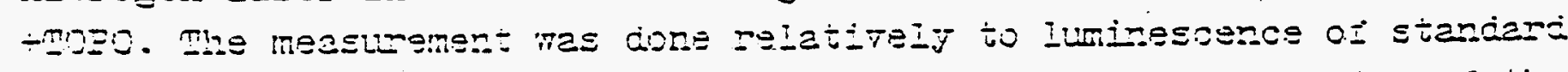

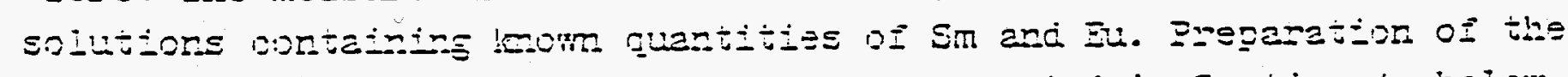

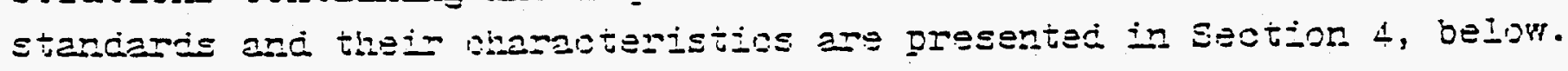
Standaric mere pregared using naturai isotopic miziures oi Sin and 피,

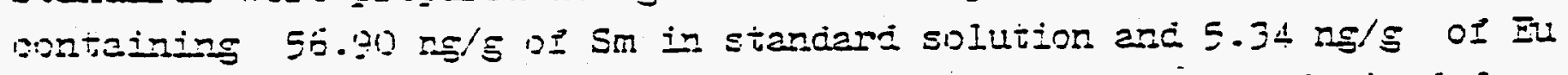
in standard solution. bonontrations in the samole were derived Irom the ratios betineen sunier al Pun pounts for equal rolunes oI soiution anaifsed and tise stuniari. These results gafe absoilute (ng/sample) Talues for the most "difficuit" gair Sm - Eu, winich rere later jusi multiplied bJ the isotope abundange itgures derived Isom the mass-spectrometry data.

\subsection{Radiochenioal separation / mass-epestrometry procedure}

The dried sanole was dissolved in soncentrated nitrie acid, erapcrated to druess and dissolved in $0.1 \mathrm{M} \mathrm{nitric} \mathrm{acid.} \mathrm{Weight} \mathrm{of}$ the empt. vial - $19.2938 \mathrm{~g}$, with solution - $22.3936 \mathrm{~g}$, solution reight - $3.0995 \mathrm{~g}$. An aliquot oI. $0.19735 \mathrm{~g}$ was taken Irom that solution for laser Iuminesience analysis or Fu and $\mathrm{sm}$ ( see in section 3.2.) Remainins sulution has besn ditided into twi parts.

mi: : E.7 


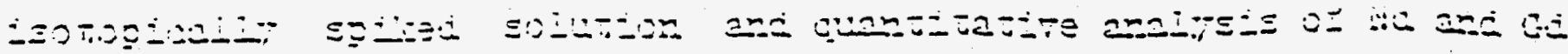

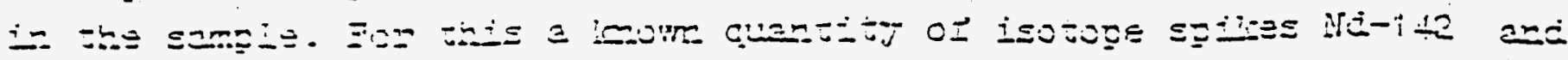

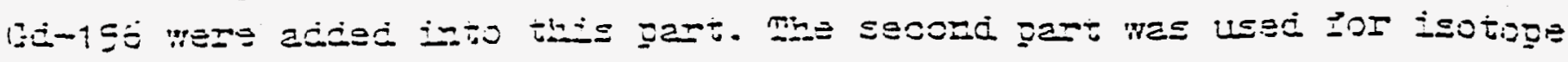

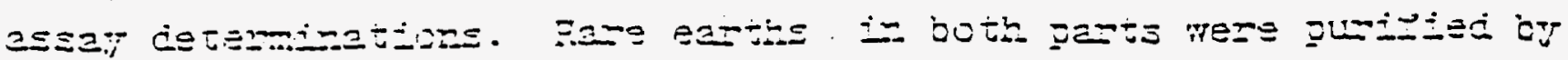

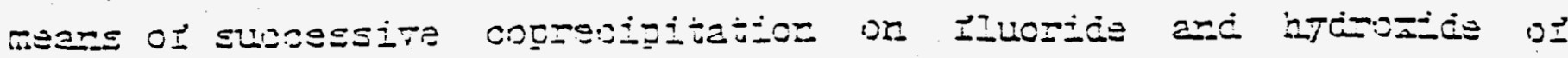

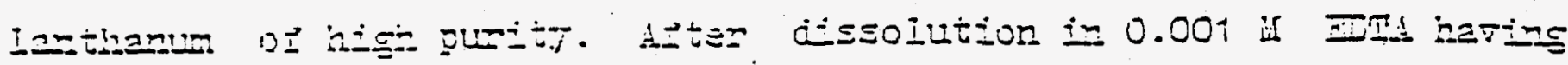

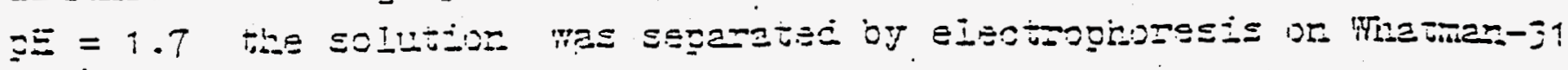

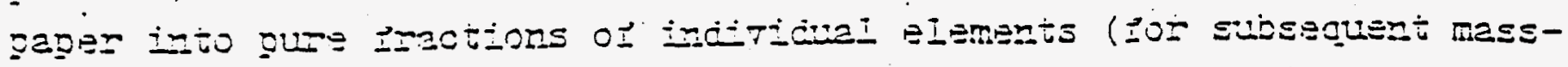

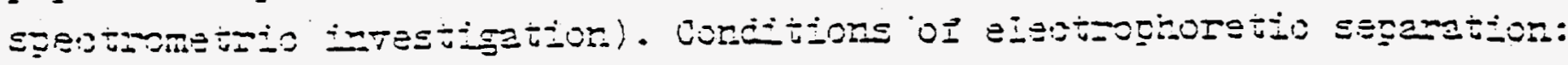
$\Xi=:-7 / \mathrm{s \pi} ; \tau=70$ minut:s.

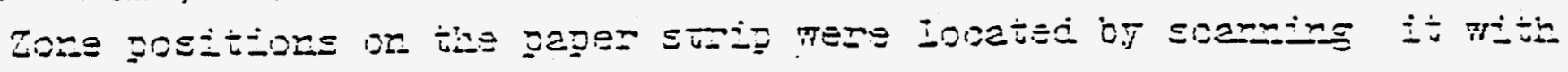

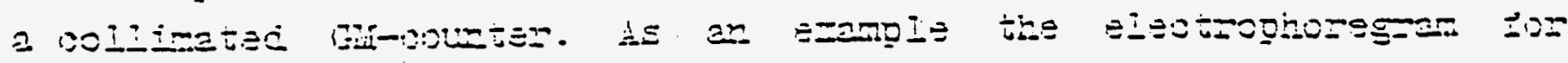

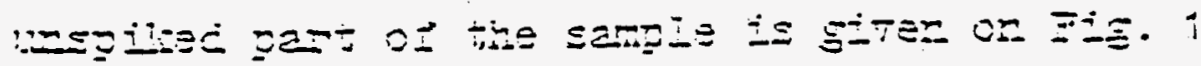

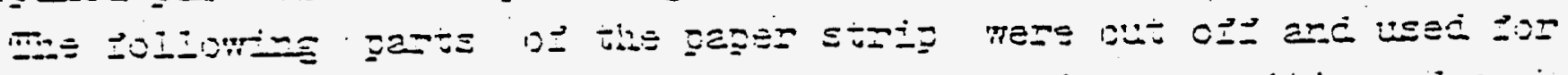

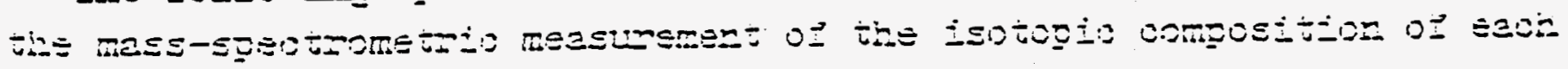
Ei=m:IT (

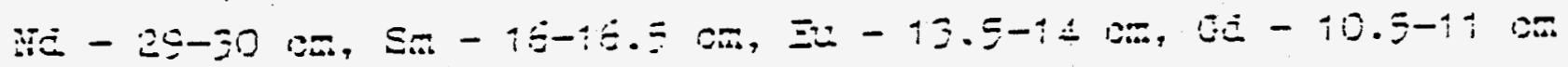

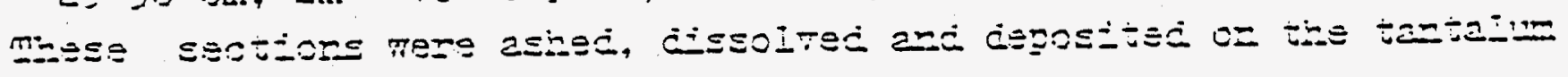

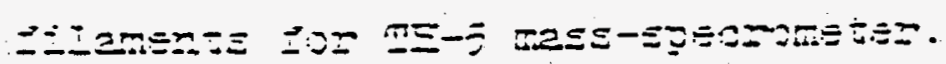

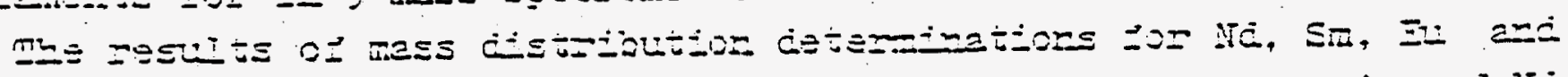

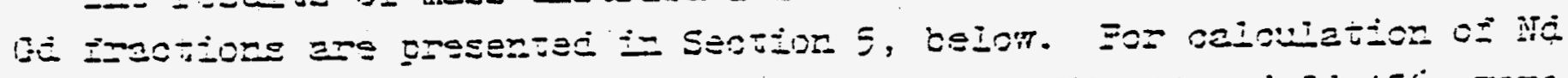

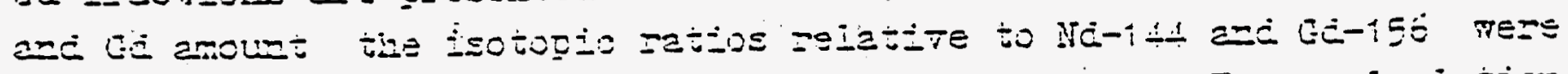

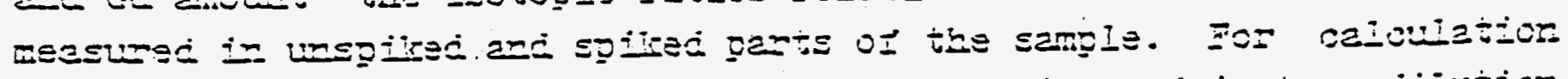

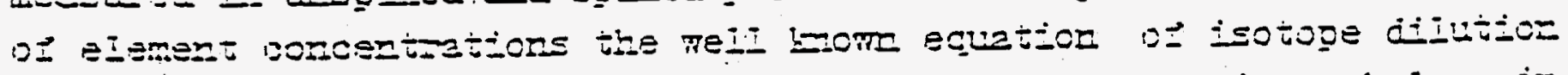

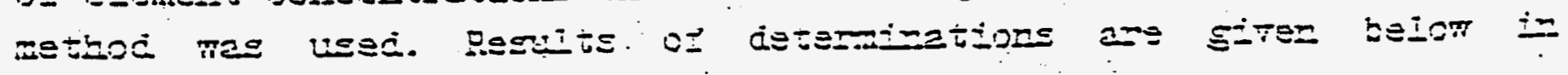
Tajies $5.1-\bar{z} .2$.

4. Stanciands used in the anaijsis =

The caijiration oI lager Iluorimeter and Durs pens made ritih ues

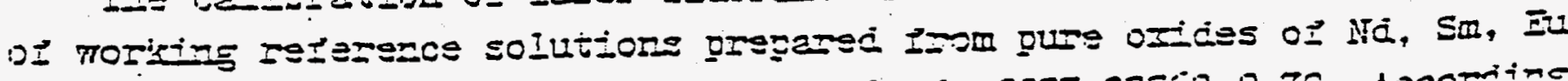

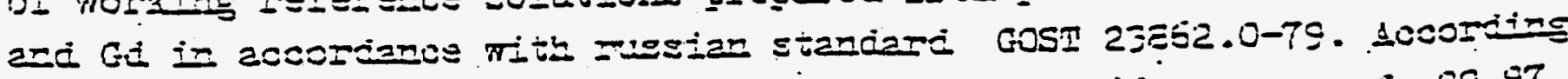
to inporation ojtained lon producer aII four orides neze oI 99.97 ,

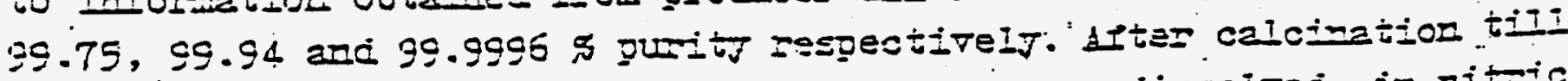

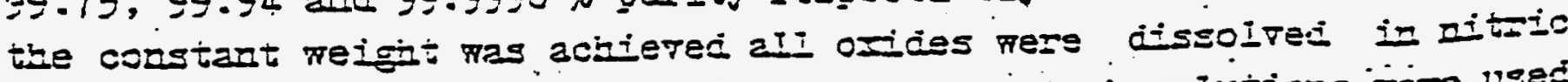

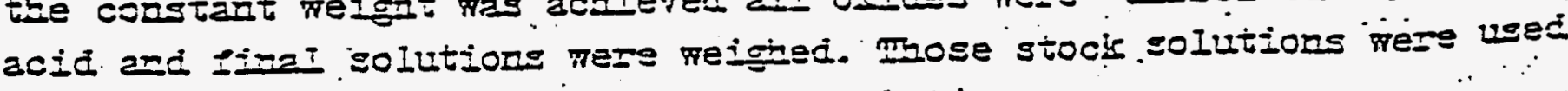
ior gregaration of porificg reflesece solutions.

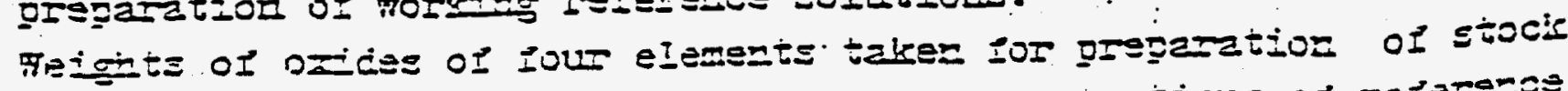

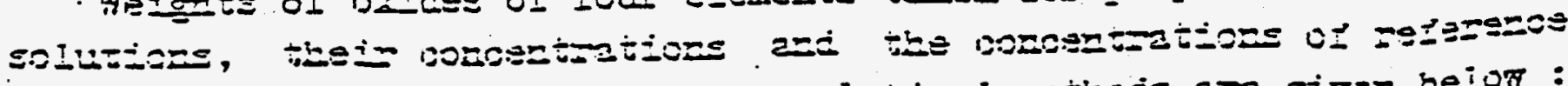

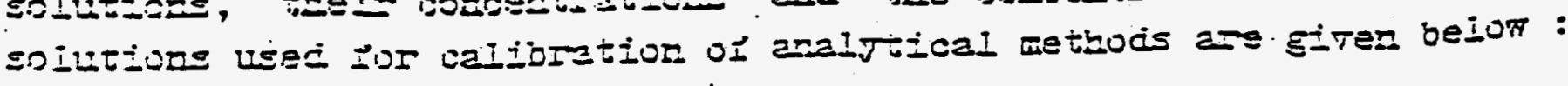




\begin{tabular}{|c|c|c|c|}
\hline & 5 & $m \Xi \vdots$ & mes.s \\
\hline ¿ & 0.35004 & 9.0171 & \\
\hline $\mathrm{Sm}$ & 0.21341 & 6.0145 & 0.4316 \\
\hline$E x$ & 0.34453 & 9.2969 & 1.0154 \\
\hline $\mathrm{CH}$ & 0.23001 & 4.9470 & 1.0803 \\
\hline
\end{tabular}

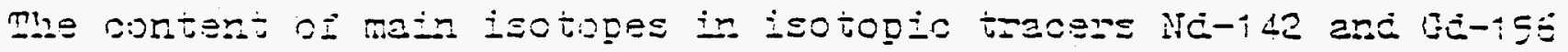
was 95.7 anc 95.9 wis respectiteiy. Mhein concentrations in soike soiutions determined by means of isptope difution inass soloctonetry

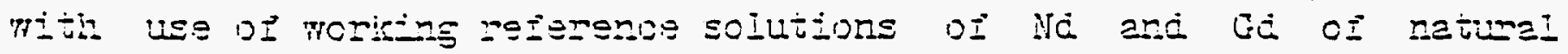
isotooic comonsition as tranens mere as foliows:

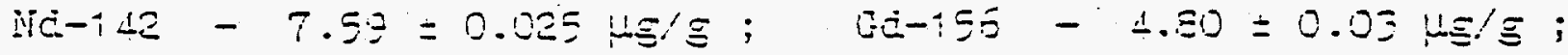

5. Inaiytical rosuits

Resuite of anaijses are presented beion in tabies $\$ .1 .$, s.2.

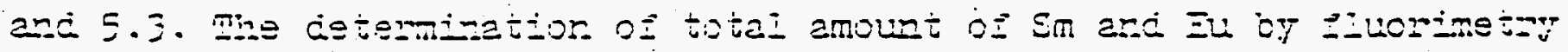
sare the vaiues $8725=100$ and $12: 3=21$ no per sampie respectiteij for

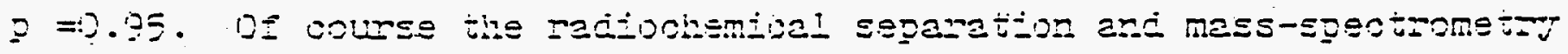

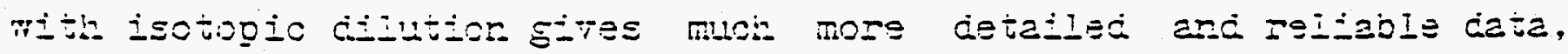
and permits to detemine the absolute nanograns per samoie ( Tabies 5.1. \& 5.2.). The SIUS analjsis ( Mable 5.j.) gives onit relativa (to Na-145) oonoentrations and does not resolte the muitielement peales. Nerertheiess we thin that somparison OI tro sets of data shows apolicabilit.7 ai sIns to some problems in this field and shouid be kept in mind winen iast analjsis oI very smail quantities is nesessarj. Te suggest. that SIMS data for masses involiting $\mathrm{Sm}$ isotodes should be doubted - probabiy because the correction faotor for $\mathrm{Sm}$ in the sample has been erroneous - due to some difference in the chemical properties of the standard and the sample analysed. Te marised the doubtull Iines rith "*". 
maie 5.1 .

Lbsoiute nangome per sanple measured by raciociremigal sesa:ation and mass-specuscmetiy with isotopis diiution method.

\begin{tabular}{|c|c|c|c|c|c|c|c|c|c|c|c|c|c|c|}
\hline \multirow{2}{*}{$\begin{array}{l}\text { Mass } \\
\text { :under }\end{array}$} & \multicolumn{5}{|c|}{ Namognams per } & \multicolumn{2}{|c|}{ sampie } & \multicolumn{4}{|c|}{$=$ error } & \multirow{2}{*}{\multicolumn{3}{|c|}{ CacioIinium }} \\
\hline & Neody & תיבוט: & & 1 & Samar & 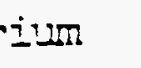 & ! & Eurs & 阳 & & 1 & & & \\
\hline $\begin{array}{l}142 \\
143 \\
141 \\
145 \\
145 \\
147 \\
145 \\
140 \\
150 \\
151 \\
132 \\
153 \\
150 \\
15 \\
150 \\
150 \\
15 \\
150 \\
150 \\
150\end{array}$ & $\begin{array}{l}257 \\
2100 \\
1000 \\
7470 \\
7 \Xi 70 \\
3910 \\
1850\end{array}$ & $\begin{array}{l}= \\
= \\
= \\
= \\
= \\
=\end{array}$ & $\begin{array}{r}5 \\
40 \\
5 \vdots \\
\vdots 2 \\
30 \\
35 \\
24 \\
150\end{array}$ & $\begin{array}{l}1 \\
\vdots \\
\vdots \\
\vdots \\
1\end{array}$ & $\begin{array}{r}294 \\
2975 \\
1200 \\
35 \\
2505 \\
196 \\
150 \\
303\end{array}$ & $\begin{array}{l}=5 \\
=100 \\
=20 \\
=5 \\
=110 \\
=25 \\
=80 \\
=20\end{array}$ & 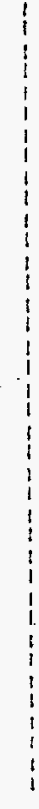 & $\begin{array}{r}23 \\
11 \\
1100 \\
70 \\
13\end{array}$ & $\begin{array}{l}= \\
= \\
= \\
= \\
=\end{array}$ & $\begin{array}{r}\frac{2}{10} \\
20 \\
7 \\
2 \\
2\end{array}$ & $\begin{array}{l} \\
\\
1 \\
\\
\\
\\
\\
\\
\\
\end{array}$ & $\begin{array}{r}.3 \\
175 \\
85 \\
825 \\
180 \\
19\end{array}$ & $\begin{array}{l}= \\
= \\
= \\
= \\
= \\
= \\
=\end{array}$ & $\begin{array}{r}.3 \\
\frac{1}{2} \\
16 \\
4 \\
4 \\
2\end{array}$ \\
\hline
\end{tabular}

Tabie 5.2.

Isotope concontrations zelative to the 145-Vi goncentration calouiated fiom measurements oy radionienical separation and mass-spectrometry mith isotopic disution method.

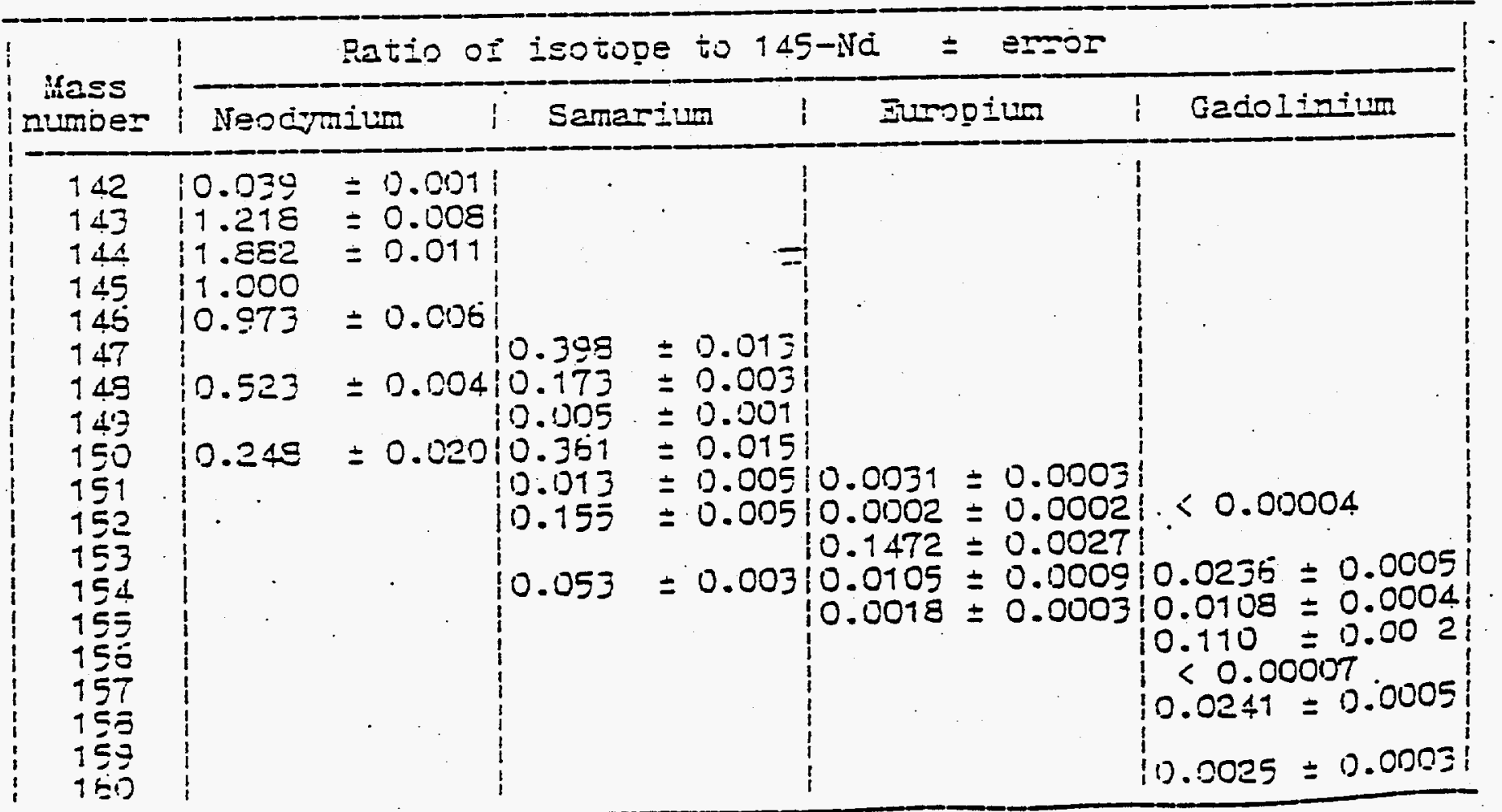


Table $5 . j$.

Isotope cocoentastions peiatige to the 1 15-id concentration neasumod by sevondary ion mass-sgevinometzy (SFis) netind

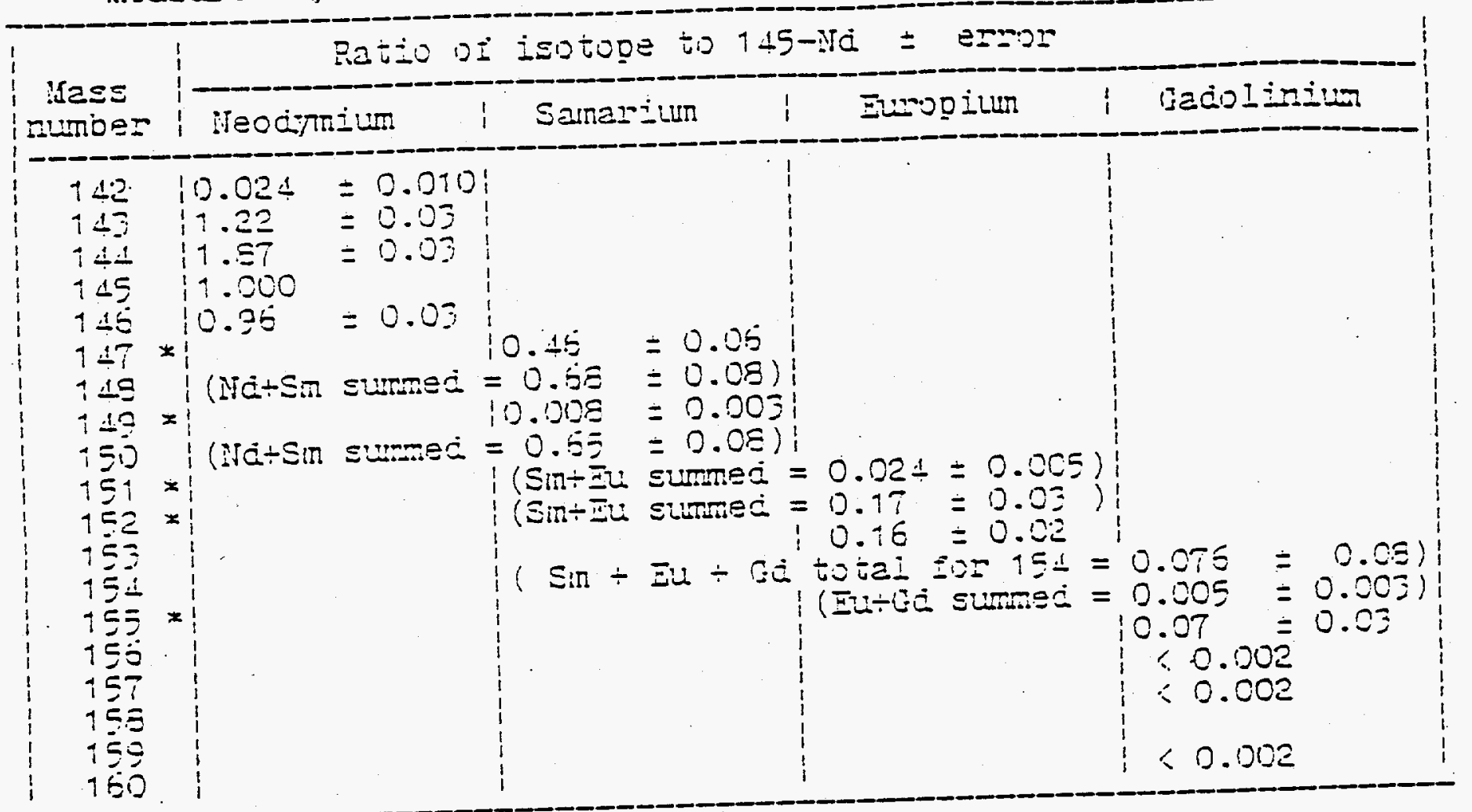




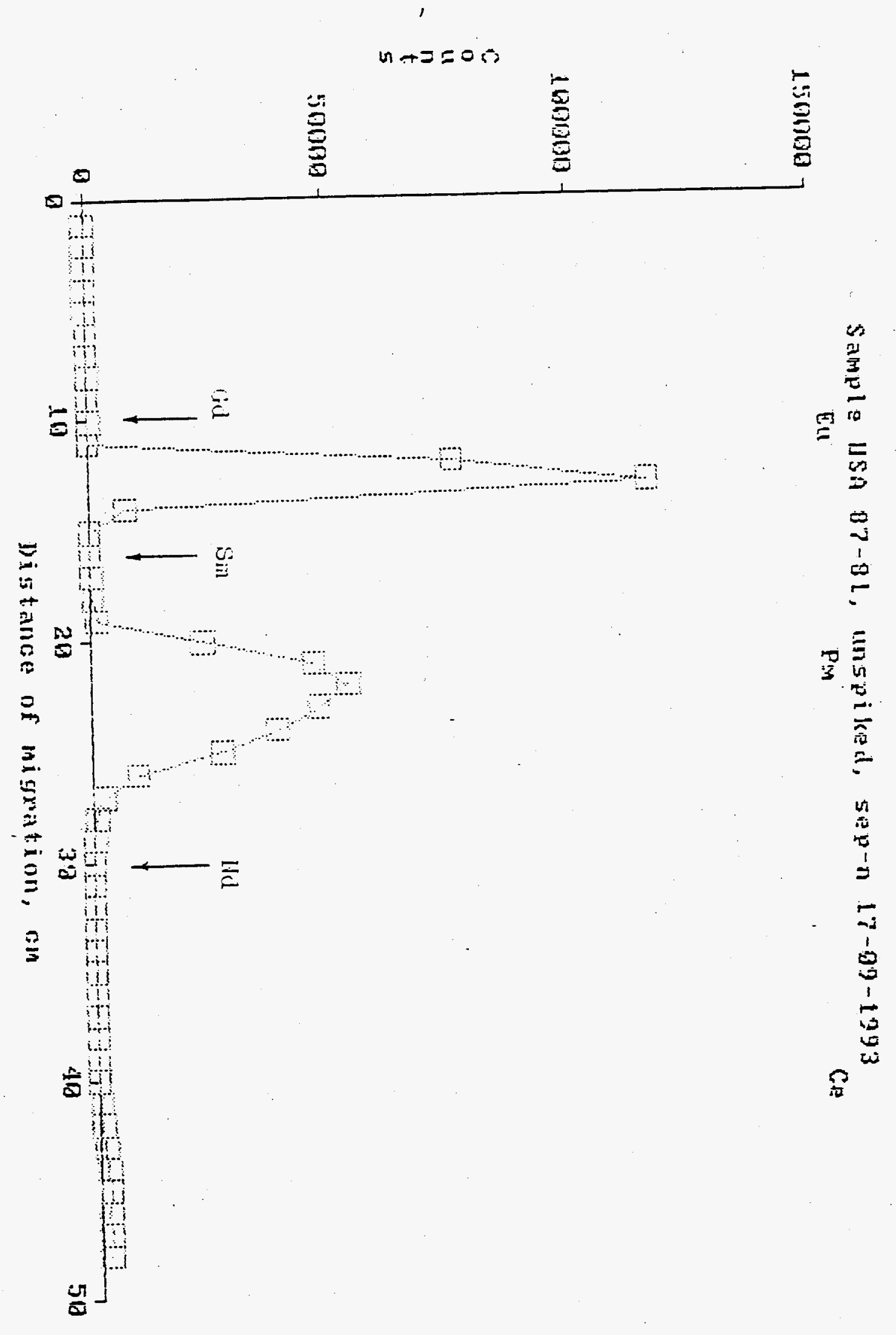

E.12 


\section{Distribution}

No. of

Copies

\section{OFFSITE}

12 U. S. Department of Energy Office of Scientific \&

Technical Information

R. Garrison

U.S. Department of Energy

Routing DP-121

Washington, DC 20545

K. Klein

U.S. Department of Energy

Routing RW-30

1000 Independence Ave., SW

Washington, DC 20585

L. Harmon

U.S. Department of Energy

Routing DP-121

Washington, DC 20545

R. Stein

U.S. Department of Energy

Routing RW-30

1000 Independence Ave., SW

Washington, DC 20585

T. Hindman

U.S. Department of Energy

Routing DP-121

Washington, DC 20545

C. Kouts

U.S. Department of Energy

Routing RW-33

1000 Independence Ave., SW

Washington, DC 20585
No. of

Copies

W. Dixon

U.S. Department of Energy

Nevada Operations Office

P.O. Box 14100

Las Vegas, NV 89114-4100

3 W. Lake

U.S. Department of Energy

Routing RW-33

1000 Independence Ave., SW

Washington, DC 20585

E.L. Wilmot

U.S.Department of Energy

Nevada Operations Office

P.O. Box 14100

Las Vegas, NV $89114-4100$

R. Kulbitskas

U.S. Department of Energy

Naval Reactors

Routing NE-60

Washington, DC 20585

J. Leonard

Office of Security Evaluations

Defense Programs - DP-4, GTN

Washington, DC 20545

F. Falci

U.S. Department of Energy

Routing DP-121

Washington, DC 20545

J.E. Bickel

U.S. Department of Energy

Albuquerque Operations Office

Albuquerque Headquarters

P.O. Box 5400

Albuquerque, NM 87115 
No. of

Copies

G.E. Garcia

U.S. Department of Energy

Albuquerque Operations Office

Albuquerque Headquarters

P.O. Box 5400

Albuquerque, NM 87115

2 M. Pellechi

U.S. Department of Energy

Idaho Operations Office

550 Second Street

Idaho Falls, Id 83401

K.G. Golliher

U.S. Department of Energy

Albuquerque Operations Office

Albuquerque Headquarters

P.O. Box 5400

Albuquerque, NM 87115

M. Heiskell

U.S. Department of Energy

P.O. Box E

Oak Ridge, TN 37831

J. Holm

U.S. Department of Energy

Chicago Operations Office

9800 S. Cass Avenue, Bldg. 350

Argonne, IL 60439

J. Allen

Battelle Columbus Division

505 King Avenue

Columbus, OH 43201-2693

S. Mann

U.S. Department of Energy

Chicago Operations Office

9800 S. Cass Avenue, Bldg. 350

Argonne, IL 60439
No. of

Copies

W. Pardue

Battelle Columbus Division

505 King Avenue

Columbus, OH 43201-2693

J. Roberts

U.S. Department of Energy

Chicago Operations Office

9800 S. Cass Avenue, Bldg. 350

Argonne, IL 60439

R. Peterson

Battelle Columbus Division

505 King Avenue

Columbus, OH 43201-2693

R. Rothman

U.S. Department of Energy

Chicago Operations Office

9800 S. Cass Avenue, Bldg. 350

Argonne, IL 60439

B. DaBelle

EG\&G Idaho, Inc.

P.O. Box 1625

Idaho Falls, ID 83145

S. Hinschberger

U.S. Department of Energy

Idaho Operations Office

550 Second Street

Idaho Falls, ID 83401

4 I. Hall

EG\&G Idaho, Inc.

P.O. Box 1625

Idaho Falls, ID 83145

W. Lattin

U.S. Department of Energy

Idaho Operations Office

550 Second Street

Idaho Falls, ID 83401 
No. of

Copies

C.V. Park

Oak Ridge National Laboratory

P.O. Box 2008

Oak Ridge, TN 37830

R. Rawl

Oak Ridge National Laboratory

P.O. Box 2008

Oak Ridge, TN 37830

R. Pope

Oak Ridge National Laboratory

P.O. Box 2008

Oak Ridge, TN 37830

T. Rowe

Oak Ridge National Laboratory

P.O. Box 2008

Oak Ridge, TN 37830

T. Stevens

Babcock and Wilcox

Nuclear Equipment Division

91 Stirling Avenue

Barberton, OH 44203

L. Shappert

Oak Ridge National Laboratory

P.O. Box 2008

Oak Ridge, TN 37830

R. Anderson

Chem-Nuclear Systems, Inc.

220 Stoneridge Drive

Columbia, SC 29210

R. Westfall

Oak Ridge National Laboratory

P.O. Box 2008

Oak Ridge, TN 37830
No. of

Copies

R. Ng

Combustion Engineeering

CE Power Systems

1000 Prospect Hill Road

Windsor, CT 06095

G.E. Whistesides

Oak Ridge National Laboratory

P.O. Box 2008

Oak Ridge, TN 37830

R. Burgoyne

GA Technologies, Inc.

Building 2, Rm 644

P.O. Box 85608

San Diego, CA 92138

L.E. Fisher

University of California

Lawrence Livermore National Laboratory

P.O. Box 808

Livermore, CA 94550

P. Aucoin

Nuclear Assurance Corporation

6251 Crooked Creek Road

Norcross, GA 30092

P. Bolton

Roy F. Weston, Inc.

955 L'Enfant Plaza SW

Washington, DC 20024

C. Johnson

Nuclear Assurance Corporation

625551 Crooked Creek Road

Norcross, GA 30092

M. Rahimi

E.R. Sonnson Associates

10461 White Granite Drive

Suite 204

Oakton, VA 22124 
No. of

Copies

R. Doman

Nuclea Packaging, Inc.

1010 S. 336th, Suite 220

Federal Way, WA 98003

J. Murphy

ANEFCO, Inc.

904 Ethan Allen Hwy.

P.O. Box 433

Ridgefield, CT 06877

C. Temus

Nuclea Packaging, Inc.

1010 S. 336th, Suite 220

Federal Way, WA 98003

C. Little

Westinghouse Electric Corp.

Waste Technology Services Div.

Box 286

Madison, PA 15663-0286

B.R. Teer

Transnuclear, Inc.

Two Skyline Drive

Hawthorne, NY 10532-2120

J. Siegel

U.S. Council for Energy Awareness

1776 I Street, N.W.

Washington, DC 20006

E. Easton

U.S. Nuclear Regulatory Commission

Office of Nuclear Materials

Saftey and Safeguards

Washington, DC 20555

J. Kearney

Edison Electric Institute

1111 19th Street, N.W.

Washington, DC 20006
No. of

Copies

A. Grella

U.S. Nuclear Regulatory Commission

Office of Nuclear Materials

Saftey and Safeguards

Washington, DC 20555

R. Lambert

Electric Power Research Institute

3412 Hillview Avenue

P.O. Box 10412

Palo Alto, CA 94304

C. Lidner

U.S. Nuclear Regulatory Commission Office of Nuclear Materials

Saftey and Safeguards

Washington, DC 20555

9 R. Williams

Electric Power Research Institute

3412 Hillview Avenue

P.O. Box 10412

Palo Alto, CA 94304

N. Osgood

U.S. Nuclear Regulatory Commission Office of Nuclear Materials

Saftey and Safeguards

Washington, DC 20555

$5 \quad$ L. Trosten

LeBoeuf, Lamb, Beiby, and McRae 1333 New Hampshire Avenue, N.W.

Washington, DC 20036

C. MacDonald

U.S. Nuclear Regulatory Commission Office of Nuclear Materials

Saftey and Safeguards

Washington, DC 20555 
No. of

Copies

J. Davis

Utility Nuclear Waste

Management Group

1111 19th Street, N.W.

Washington, DC 20036

J. Roberts

U.S. Nuclear Regulatory Commission

Office of Nuclear Materials

Saftey and Safeguards

Washington, DC 20555

R. Jones

JNT, Inc.

P.O. Box 1510

Los Gatos, CA 95031-1510

L. Rouse

U.S. Nuclear Regulatory Commission

Office of Nuclear Materials

Saftey and Safeguards

Washington, DC 20555

R. Chappell

U.S. Nuclear Regulatory Commission

Office of Nuclear Materials

Saftey and Safeguards

Washington, DC 20555

C. Withee

U.S. Nuclear Regulatory Commission

Office of Nuclear Materials

Saftey and Safeguards

Washington, DC 20555

D. Hopkins

U.S. Nuclear Regulatory Commission

Office of Nuclear Regulatory Research

Washington, DC 20555

B. Rasmussen

Duke Power Company

P.O. Box 33189

Charlotte, NC 28242
No. of

Copies

W. Lahs

U.S. Nuclear Regulatory Commission Office of Nuclear Regulatory Research

Washington, DC 20555

W.B. Andrews

Science Applications International

Corporation

Nevada Nuclear Waste Storage

Investigations

Valley Bank Center

101 Convention Center Drive

Las Vegas, NV 89109

C. Orth

U.S. Department of Transportation

RRS-32

440 Seventh Street, SW

Washington, DC 20590

D. Brodnick

Florida Power \& Light Co.

P.O. Box 14000

Juno Beach, Fl 33408

M. Wangler

U.S. Department of Transportation

Office of Materials Transportation

440 Seventh Street, SW

Washington, DC 20590

J. Fisher

Virginia Power Company

P.O. Box 2666

Richmond, VA 23261

V. Pareto

Yankee Atomic Electric Co.

1617 Worcester Road

Framington, MA 01701

M. Smith

Virginia Power Company

P.O. Box 2666

Richmond, VA 23261 
No. of

Copies

L. McCarten

Northern States Power Co.

414 Nicollet Mall

Minneapolis, MN 55401

J. Ladesich

Southern California Edison Co. 2244 Walmut Grove Avenue

Rosemead, CA 91770

H. Shimon

Wisconsin Electric Power Co.

231 West Michigan St.

Milwaukee, WI 53201

L. Friel

Western Interstate Energy Board

3333 Quebec Street

Denver, CO 80207

K. Folk

Southern Company Services

P.O. Box 1625

Birmingham, AL 35202

Douglas Larson, Exec. Dir.

Southern States Energy Board

3091 Govenors Lakes Drive

Suite 400

Norcross, GA 30071

D. Frech

Duke Power Company

P.O. Box 33189

Charlotte, NC 28242

R.W. Lynch

Sandia National Laboratory

Division 6300

Albuquerque, NM 87185
No. of

Copies

Barbara Foster

National Conference of State Legislatures

Energy Science and Natural Resources

1050 17th Street, Suite 2100

Denver, CO 80625

25 TTC Library

Attn: TTC Master File

Sandia National Laboratory

Division 6320

Albuquerque, NM 87185

Gail Chehak

National Congress of American Indians

804 D Street, N.E.

Washington, DC 20002

T.L. Sanders

Sandia National Laboratory

Division 6322

Albuquerque, NM 87185

G.C. Allen

Sandia National Laboratory

Division 6322

Albuquerque, NM 87185

M.C. Brady

Sandia National Laboratory

Division 6322

Albuquerque, NM 87185

P.W. Dean

Sandia National Laboratory

Division 8024

Albuquerque, NM 87185

R.I. Ewing

Sandia National Laboratory

Division 6322

Albuquerque, NM 87185 
No. of Copies

R.E. Glass

Sandia National Laboratory Division 6322

Albuquerque, NM 87185

K. Seager

Sandia National Laboratory

Division 6322

Albuquerque, NM 87185

D.L. Hartley

Sandia National Laboratory

Division 6000

Albuquerque, NM 87185

J.E. Stiegler

Sandia National Laboratory

Division 6320

Albuquerque, NM 87185

3 W.I. Klein

Sandia National Laboratory

Division 3151

Albuquerque, NM 87185

8 C. Ward

Sandia National Laboratory

Division 3141-1

Albuquerque, NM 87185

5 S.A. Landenberger

Sandia National Laboratory Division 3141

Albuquerque, NM 87185

R.E. Luna

Sandia National Laboratory

Division 6321

Albuquerque, NM 87185

Sandia National Laboratory

Division 6322

Albuquerque, NM 87185
No. of

Copies

\section{FOREIGN}
A. Charlier
Belgonucleaire
23 rue du Champf de Mars
B-1050 Bruxelles
BELGIUM
M. Doucet
Belgonucleaire
23 rue du Champf de Mars
B-1050 Bruxelles
BELGIUM

M. Ermont

Centre de'Etudes Mucleaires

B.P. 6

F-92260 Fontenay-aux-Roses

FRANCE

\section{Tomozo Koyama}

PNC, Power Reactor \& Nuclear Fuel

Development Corporation

1-9-13, Akasaka

Minato-Ku, Tokyo

JAPAN

L. Maubert

Centre de'Etudes Mucleaires

B.P. 6

F-92260 Fontenay-aux-Roses

FRANCE
P. Landeyro
ENEA, CRE-Casaccia
1-00100 Roma
ITALY
G. Poullot
Centre de'Etudes Mucleaires
B.P. 6
F-92260 Fontenay-aux-Roses
FRANCE 
No. of

Copies

S. Mancioppi

Comitato Nazionale per l'Energia

Nucleare

Viale Regina Margherita 125

I-00100 Roma

ITALY

L.M. Farrington

British Nuclear Fuels PLC

Technical Services

R101 Ruterford House

Risley, Warrington WA3 6 AS

UNITED KINGDOM

T. Matsumoto

PNC, Power Reactor \& Nuclear Fuel

Development Corporation

1-9-13, Akasaka

Minato-Ku, Tokyo

JAPAN

G.F. Gualdrini

Comitato Nazionale

per la Ricerca e per lov Sviluppo

Dellenergia Nuleare

E Delle Energie Alternative

Via G. Mazzini 2

40138 Bologna

ITALY

D. Mennerdahl

AB Erling Mennerdahl

P1 457

S-18699 Vallentuna

SWEDEN

G. Kamelander

Oesterr Forschungszentrum

Seibersdorf Ges. m.b.H.

Lenaugasse 10

A-1082 Vienna

AUSTRIA
No. of

Copies

Y. Naito

JAERI-Nuclear Fuel Facility

Evaluation Laboratory

Nuclear Safety Research Centre

Tokai ura, Naka-gun

Ibaraki-ken 319-11

JAPAN

R. Keay

British Nuclear Fuels PLC

Technical Services

R101 Ruterford House

Risley, Warrington WA3 6 AS

UNITED KINGDOM

Dr. Iwao Kobayashi

Deputy Director

Dept. fo Fuel Safety Research

JAERI

Tokai-mura, Ibaraki-ken

319-11, Japan

Enrico Sartori

OECD

NEA Data Bank

91191 Gif-sur-Yvette CEDEX

FRANCE

J.M. Paratte

Federal Institute for Reactor Research

CH-5303 Wurenlingen

SWITZERLAND

H.H. Schweer

Physikalisch-Technische Bundesanstalt

Bundesallee 100D-3300 Braunschweig

FEDERAL REPUBLIC OF GERMANY

W. Weber

Gesellschaft fur Reaktorsicherheit

Forschungsgelande

D-8046 Garching bei Munchen

FEDERAL REPUBLIC OF GERMANY 
No. of

Copies

F. Siciliano

ENEA - Centro Comb Trisaia

S. S. 106 Jonica, Km. $419+500$

I-75025 Policoro (Matera)

ITALY

Jose M. Conde Lopez

CONSEJO DE SEGURIDAD NUCLEAR

Justo Dorado 11

28040 MADRID

SPAIN

W. Thomas

Gesellschaft fur Reaktorsicherheit

Forschungsgelsande

D- 8046 Garching bei Munchen

FEDERAL REPUBLIC OF GERMANY

G. Walker

Safety and Reliability Directorate

UK Atomic Energy Authority

Culcheth, Warrington WH3 4NE

Royaume-Uni

UNITED KINGDOM

F. Wasastjerna

Technical Research Center of Finland

Nuclear Engineering Laboratory

P.O. Box 169

SF-00191 Helsinki

FINLAND
No. of

Copies

\section{ONSITE}

3 DOE Richland Operations Office

D.C. Langstaff

K8-50

J. Peterson

A7-89

J.J. Sutey

K8-50

15 Pacific Northwest Laboratory

S.R. Bierman (5)

K8-34

E.D. Clayton

K8-41

S.W. Heaberlin

K8-34

R.A. Libby

K8-41

R.J. Talbert

K8-34
Publishing Coordination

Technical Report Files (5)

Distr.9 